\title{
Carcharodon megalodon from the Upper Miocene of Denmark, with comments on elasmobranch tooth enameloid: coronoïn
}

\author{
SVEND ERIK BENDIX-ALMGREEN
}

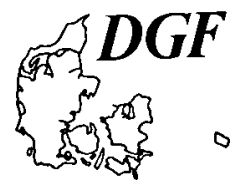

Bendix-Almgreen, S. E.: Carcharodon megalodon from the Upper Miocene of Denmark, with comments on elasmobranch tooth enameloid: coronoïn. Bull. geol. Soc. Denmark, vol 32, pp. 1-32, Copenhagen, November, 15th, 1983. https://doi.org/10.37570/bgsd-1983-32-01

(1)

C. megalodon, not previously known from deposits in Denmark, is recorded from a large, but imperfect tooth derived from the marine clay exposed at the type locality for the Upper Miocene Gram Formation. Detached, large vertebral centra from this locality, probably belonging to the same species, are considered as well as the nomenclature and phylogenetic relationships of the genus and species. A revised list of the Gram clay elasmobranch assemblage is included.

Elasmobranch tooth enameloid, now distinguished under the term coronoin and perfectly preserved in the C. megalodon tooth, is a mesodermally derived, hypermineralized hard substance. Its ultrastructural, histological and ontogenetic characteristics in elasmobranchs in general are touched upon and considered in comparison with similar features of other enameloids including acrodin of actinopterygians and varieties of pleromin occurring in dipnoan and chimaeroid dentitions. Coronoïn and acrodin (both differing from pleromins in all essential features of ontogenetic formation and growth), are characteristic of elasmobranchs and actinopterygians, respectively, and these two groups separated phylogenetically far back in the Palaeozoic. It is not unexpected, therefore, that coronoïn and acrodin are found to be structurally distinguishable from each other.

S. E. Bendix-Almgreen, Geologisk Museum, Øster Voldgade 5-7, DK-1350 København K., Denmark, January 15th 1983.

Бендикс-Альмгреен, С. Э.: Carcharodon megalodon из верхнего миоцена Дании, с комментарием о короноине - зубном эмалеподобном веществе эласмобранхов. Бюл.геол.бщ. Дании, том 32, сгр. xxxx, Копенгаген.

Больщой, хотя не полностью сохранивццийся зуб акулы $\dot{C}$. megalodon, раньце не известны в неогеновых осадках Дании, был найден в морских глинах тинового выхода верхнемиоценовой грамской формации. Разрозненные крупные сердцевинные части позвонков этого выхода вероятно принадлежат тому же виду и описываются в настоящей статье. Обсуждается номенклатура и филогенетические отнопения этого рода и вида акул. ІІриводится также пересмотренный список эласмобранхов из грамских глин.

Зубное эмалеподобное вецество эласмобранхов, известное теперь под названием короноин, совершенно сохранилось в описываемом зубе C. megalodon. Оно представляет собой гиперминерализованное твердое вещество мезотермального происхождения. В статье затрагивается ультраструктурная, гистологическая и онтогенетическая характеристика короноина эласмобранхов вообще, которая рассматривается в сравнении со сходными чертами эмалеподобного вепества зубов других групі, вклюгая акродин лучеперых и разновидности пшеромина зубного аппарата двоякодыпапих и химер. Как короноин так и акродин отличаются от шлеромина во всех основных чертах онтогенетического формирования и роста и характерны соответственно для акуловых и лучеперых. Эти две групшы филогенетически разделились уже в палеозойское время, поэтому не удивительно, тто короноин и акродин структурно отличаются друг от друга.

The Carcharodon megalodon tooth (figs 1A-C, 2A) which provoked this paper is the first of its kind known from the Danish Upper Miocene deposits. It derives from the Gram Clay of these deposits and presents the only unequivocal evidence for the appearance of this species so far to the north in the Miocene sea which covered substantial areas of northwestern Europe.
The genus $C$. has been reported previously from Danish Cenozoic deposits. A single tooth, of undetermined species, was recorded by Rasmussen (in Milthers et al. 1957; Rasmussen 1966: 85) from the Hodde clay which is slightly older than, but located within the same area as, the Gram clay (Rasmussen 1966, 1968). Another detached tooth, which can be referred to the spe- 
cies $C$. turgidus and which has not been recorded previously, derives from dislocated Oligocene deposits at Svendsmølle (ENE of Vejle) in eastern Jutland.

Occurrences of $C$. -like tooth types (representing euselachians whose phyletic/systematic affinities still remain obscure, see below) include Procarcharodon auriculatus from the Lower Middle Eocene deposits at Trelde Næs (E Jutland; cf. Hoch 1975; Heilmann-Clausen in Friis et al. 1981) and Palaeocarcharodon landanensis (Rosenkrantz 1920, who referred to the two imperfect specimens as Carcharodon sp.) from $\mathrm{Pa}-$ leocene deposits in the Copenhagen area.

Davis (1890) recorded C. rondeleti as part of the Danian fish fauna from Faxe (S Sjælland), but Ravn (in Milthers 1908) doubted that the tooth in question derived from the Faxe deposits, because it diverges strongly in appearance and preservation from all other elasmobranch teeth found there. Investigation by S. B. Andersen (pers. comm.) of coccoliths preserved in calcareous sediment filling cavities in the tooth base proves that Ravn was correct when he suspected an erroneous labelling of the specimen. The coccolith content lacks all typical Faxe representatives (e.g. Cruciplacolithus tenuis, Chiasmolithus danicus, Thoracosphaera operculata) and comprises species of among others Helicopontosphaera and "Discoaster", both genera indicating that the tooth derives from deposits not older than the Eocene, but probably younger than that.

\section{General comments on the Gram clay elasmobranchs}

Detached elasmobranch teeth and other remains including vertebral centra and scales are comparatively rare fossils in the marine Upper Miocene Gram clay (Gram Formation: Rasmussen 1956, 1961a,b, 1966; see also Kristoffersen 1972, 1973; Piasecki 1980) exposed in various brickclay pits of western Jutland. However, over the years sizeable collections of these fossils have accumulated in the Geological Museum (University of Copenhagen), the Danish Geological Survey (D.G.U., Copenhagen) as well as in several private collections and now, too, in the new Natural History Museum (Midtsønderjyllands Museum) in Gram.
This group of vertebrate fossils has received little attention and the planned investigation of the Danish material by Kruchow (cf. Kruchow 1961: 45, footnote) never materialized in print. Published records are limited. Rasmussen (1963) listed some genera and species from material collected by him and this list was requoted in slightly amended form by Roth (1978). Another record occurred recently in a semi-popular article by Richter (1978) who mentioned i.a. the Carcharodon megalodon tooth which is the nucleus of the present contribution.

The Gram Formation elasmobranch assemblage, listed here in updated nomenclature form and with some new additions, comprises:

\section{Euselachii}

Order Hexanchiformes

Family Hexanchidae: Hexanchus primigenus

Order Squaliformes

Family Squalidae

Subfamily Squalinae: Squalus cf. acanthias

Order Lamniformes

Family Odontaspidae: Odontaspis sp.

Family Lamnidae: Isurus hastalis

Isurus escheri

Isurus sp.

Carcharodon megalodon

Family Cetorhinidae: Cetorhinus maximus

Order Carcharhiniformes

Family Scyliorhinidae: Scyliorhinus cf. coupatezi

Family Carcharhinidae: Galeocerdo sp.

\section{Batoidei}

Order Rajiformes

Family Rajidae: Raja sp. sp.

\section{Batoidei}

Order Rajiformes

Family Rajidae: Raja sp. sp.

Generally speaking this elasmobranch assemblage seems to differ little from, though possibly indicating a slightly poorer fauna than, the material from broadly contemporaneous marine deposits from e.g., Belgium, the Netherlands, NW Germany, and $N$ France and dealt with in papers 
by Leriche (1920a, b, 1926, 1936, 1951), Geyn (1937), Kruchow $(1959,1960,1961,1964,1965$; in Weiler 1961: 51) Bosch (1964, 1969, 1978, 1980), Bosch et al. (1975), Ceuster (1976) and others.

The availability of material is not responsible for the lack of information on Danish Miocene elasmobranch fossils and can be contrasted with the plentiful results published on molluscs from the same marine deposits (Ravn 1907; Sorgenfrei 1940, 1958, 1961; Rasmussen 1954, 1956, 1958, 1959, 1961a, b, 1966, 1968). Other invertebrate fossils (e.g. crustaceans), however, remain largely unrecorded. Besides elasmobranchs the Danish Upper Miocene vertebrate fossils include actinopterygians, chelonians, seals and whales which are only now being subjected to serious studies (Bendix-Almgreen \& Roth 1976; Roth 1978, 1980; Gaemers 1978). Foraminifera (Kristoffersen 1972, 1973) and dinoflagellates (Piasecki 1980) have been studied in relation to the detailed stratigraphic subdivision of Danish Upper Miocene deposits including the Gram Formation.

\section{Carcharodon megalodon Agassiz}

Syn. Procarcharodon megalodon (Casier 1960) Megaselachus megalodon (Glikman 1964) See further Leriche 1929: 412-418. Menesini 1969: 22-23.

Provenance and preservation of the material

The tooth representing this imperfectly known species of the genus $C$. (pertaining to the family Lamnidae of the order Lamniformes; cf. Compagno 1973: 28) derives from the deposits exposed in the Gram brickworks pit, the type locality of the Gram Formation (Upper Miocene: Rasmussen 1966; see also Bosch et al. 1975; Piasecki 1980).

The specimen is incomplete (figs $1 \mathrm{~A}-\mathrm{C}, 2 \mathrm{~A}$ ) but all fracture surfaces and scars are fresh showing sharp edges. The character of some of the scars clearly indicates that the tooth has passed with the embedding clay through the macerating and sorting machinery at the brickworks, and the missing one third was not recovered when the specimen was found. Pyrite occurs within the specimen and as encrustations on the surface (particularly that of the base), but has not caused any damage or concealment of significant features.

Some 20 detached, large vertebral centra which probably belong to $C$. megalodon are also dealt with below. They were found in close proximity to each other, all embedded in large irregularly shaped nodules of hardened Gram clay (fig. 3; see also Bendix-Almgreen 1982b), and no doubt derive from a single fish. Due to compaction in the deposits the interior calcifications have collapsed in most of the centra, but a few larger ones have suffered less distortion. They were found deep down in the Gram clay and apparently in the same area of the pit from where the tooth came.

The $C$. megalodon tooth from Gram belongs to Mr. Julius Knoop (Naturkundliche Sammlung), Niebüll - Gotteskoog, BDR-2260. The vertebral centra were recovered by the writer and co-workers from the Geological Museum (University of Copenhagen) and are kept in the collections of fossil vertebrates of this museum (Vertebratpalæontologisk Samling) where the specimens with MGUHVP nos. in the present paper belong.

\section{Descriptions}

The tooth: All features preserved are distinctive for $C$. megalodon teeth (figs 1A-E, 2A). The specimen is now $15 \mathrm{~cm}$ high, but a restoration (fig. 2A) based on comparison with similarly shaped teeth of the species figured by Leriche (1926) indicates that its original height may have been about $16 \mathrm{~cm}$ and that it probably measured approx. $12 \mathrm{~cm}$ across where broadest. These are rough size estimates, but even so this specimen clearly lies among the largest known teeth of the species.

Despite the presence of pyrite, even minute details such as the ultrastructure of the enameloid substance (referred to now as coronoïn, BendixAlmgreen 1982a) covering the coronal surface are perfectly preserved. This will be dealt with separately in comparison with other tooth enameloids (see below, p. 8-16).

The stout crown recurves slightly towards the top and is basally almost as thick as, and was probably broader than, the base (figs 1A-C, 2A). The curvature of the preserved sections of its serrated cutting edges (figs $1 \mathrm{~A}, \mathrm{C}, 2 \mathrm{~A}$ ) indicates 


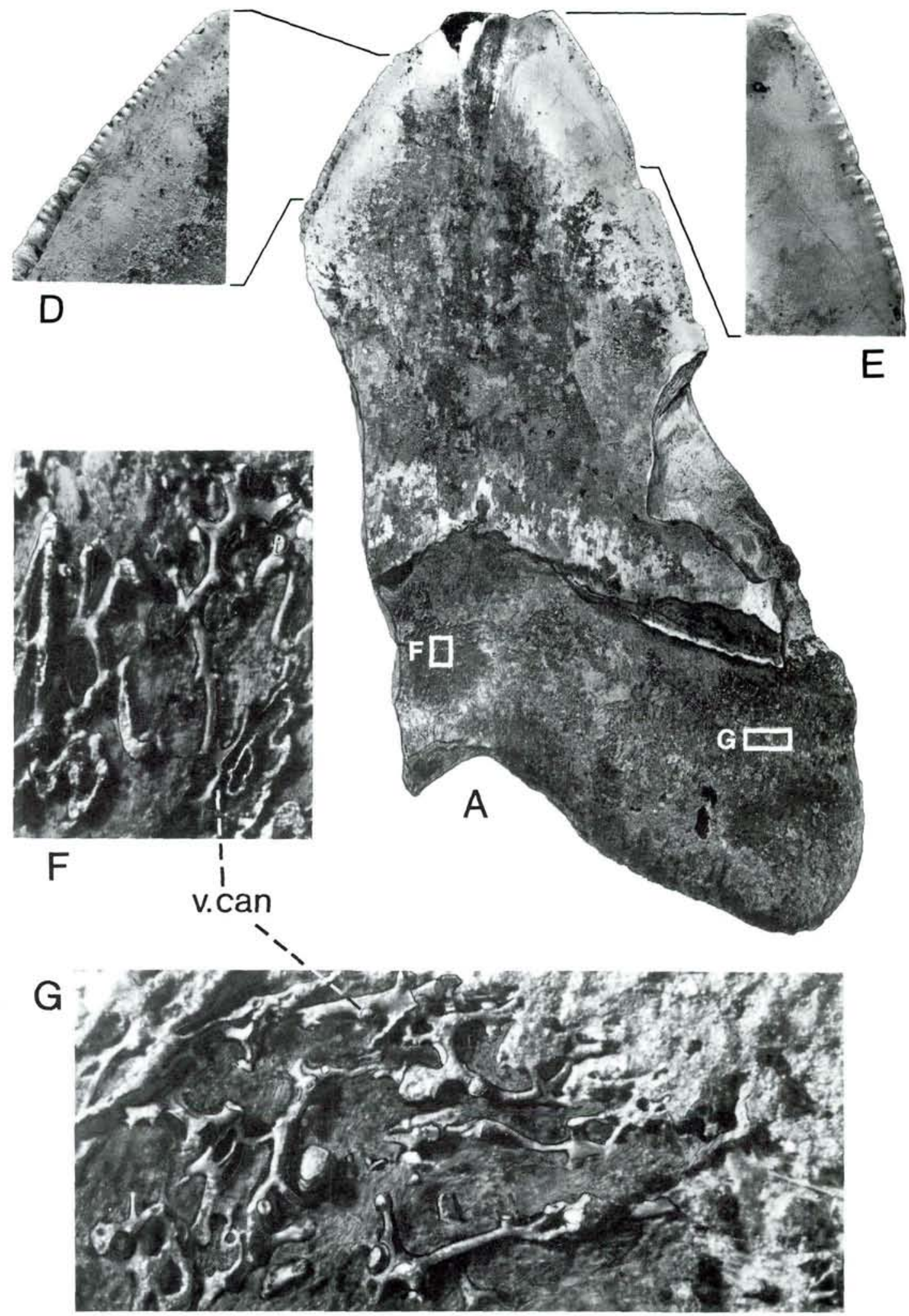

Fig. 1. Carcharodon megalodon, Gram Formation, Upper Miocene, Denmark. Right upper jaw tooth (probably of the first tooth row) shown in labial (A), edge (B) and lingual (C) views; approx. $x$. D-E: Worn cutting edge serration, labial view; approx, $x 2$. F-H Natural casts (in pyrite) of minute canals from the complex, interconnecting blood supply and drainage system of the tooth base, exposed at locations indicated in B and C; approx. $\mathrm{x} 30$. 


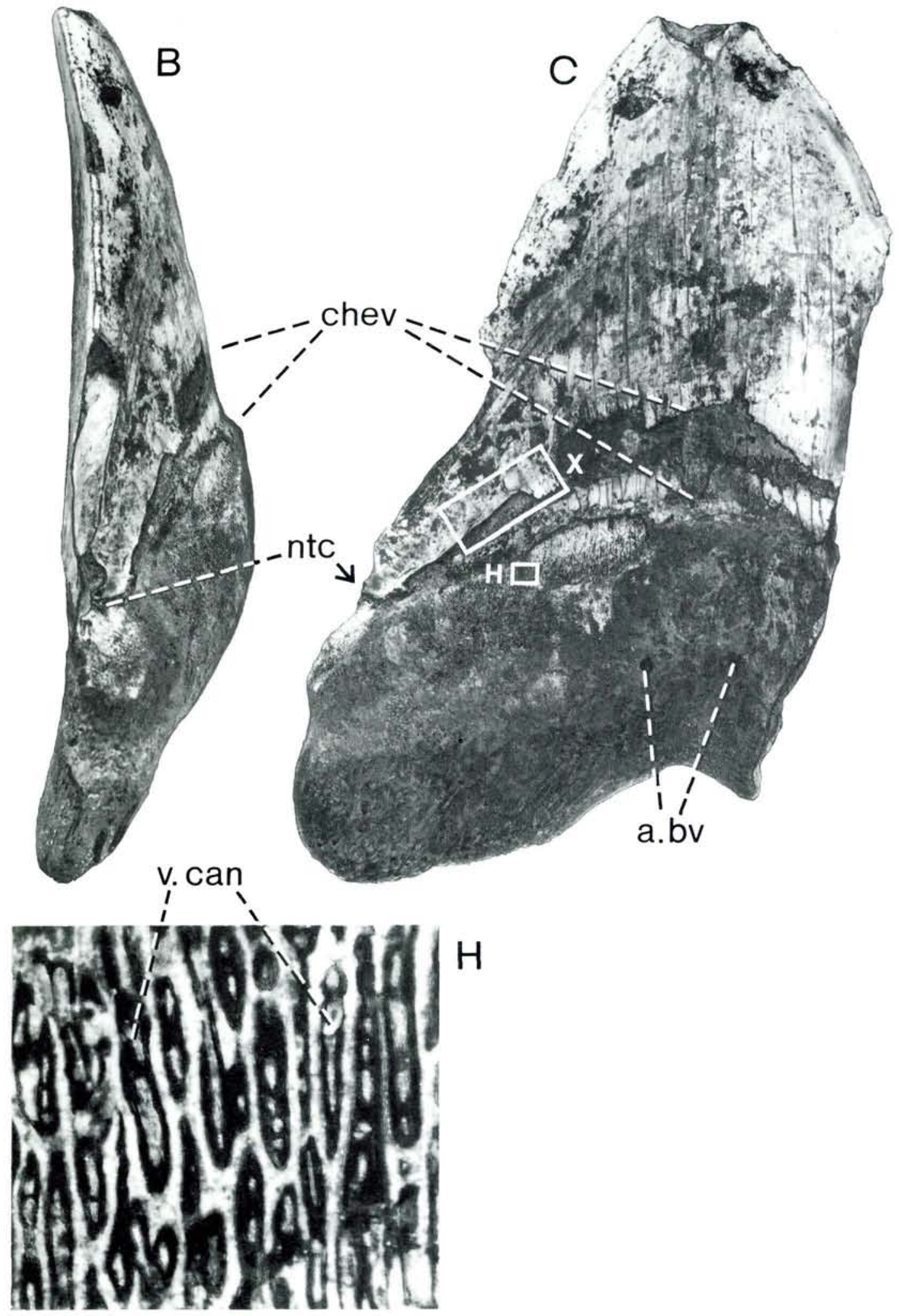

$a . b v$, apertures for main blood vessels; chev, chevron shaped depression; $n t c$, notch indicating original presence of semiseparate, probably low cusp-like protrusion; v.can, replica in pyrite of tiny blood vessels; $x$, area shown in approx. $x 8$ magnification in fig. $4 \mathrm{~A}$. 

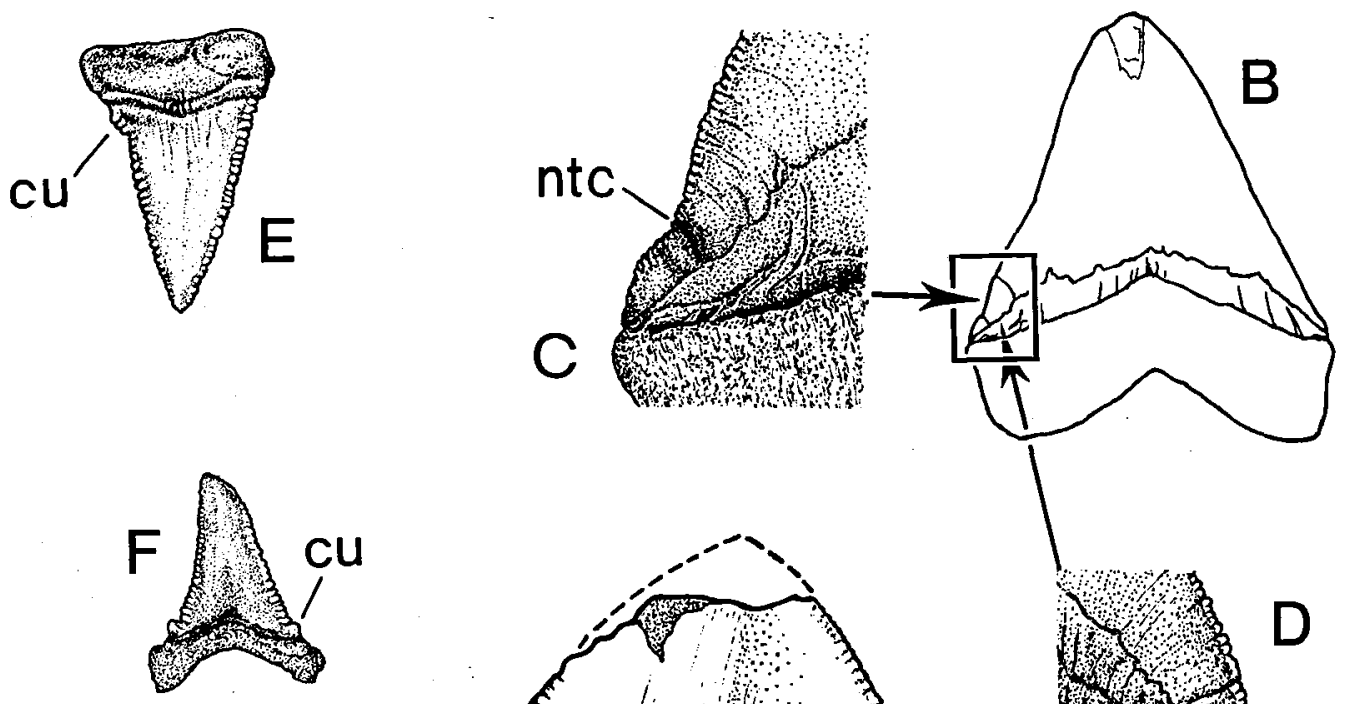
that the crown was somewhat asymmetrical in shape suggesting that the tooth in its entire form most closely resembles those which, according to Leriche (1926: e.g. fig. 187), occupied positions in the adsymphysial tooth row located on the pars palatinum of the right palatoquadrate.

The cutting edge serration consists of small studs (about 13 per $\mathrm{cm}$ on average: fig. 1D-E) all of them entirely covered by coronoin and showing abrasion of the tops which (like other less distinct wear marks) indicate that the tooth has been in function for some time during life.

A deep notch discernible at the margin of the lingual surface (ntc, fig. 1B-C) indicates that the crown was flanked on this side by a lateral "cusp". It probably formed a broad but low serrated protrusion as seen in many other $C$. megalodon teeth of similar size and shape (fig. 2B-D) and like these a corresponding "cusp" was presumably present on the other side of the crown.

The coronoin covering the lower part of the crown, on both the labial and lingual side, is developed only as a thin sheet and has been subject to damage particularly that which covers the characteristic chevron-shaped area on the lingual side (chev, fig. 1B-C).

The base, shaped like an inverted V, has a fairly steep contact surface towards the jaw presumably indicating that the supporting edge of the jaw (whose shape, size and other characters are unknown so far in this species) was narrow and steep-sided somewhat like in extant $C$. carcharias. The surface of the base is rough. This may have added extra mechanical strength to the support of the tooth which was held in position during life by anchoring connective tissue fibres extending from the tough tissue cover of the jaw and penetrating into the hard substance of the base as in recent material and, for that matter, in other fossil material too, as indicated by a variety of microstructural features (see e.g. Ørvig 1966).

In addition to two larger apertures situated on the lingual side ( $a . b v$, fig. 1C) the base surface exhibits numerous minute ones, which gave access to tiny blood-vessels forming the highly complex and interconnecting supply and drainage system which meanders through the entire interior of the base and crown (figs 1F-H, 4B). The vertebral centra: The 20 or so imperfectly preserved specimens range in diameter from about $10 \mathrm{~cm}$ to $23 \mathrm{~cm}$. The few larger centra that are less affected from compaction in the deposits, permit an estimate of their original front to back dimensions ranging from about $5 \mathrm{~cm}$ to $8 \mathrm{~cm}$. The vertebral centra are, accordingly, high and short structures and all show a thick strongly calcified zone along their articular surfaces (c.art, fig. 3). Judging from observations during excavation, the interior calcification pattern of the centra consists of plate-like exochordal radii coalesced by fairly thick concentric annuli into a dense mass. This shows in vertical transverse section a somewhat lace-like appearance; a comparison emphasized by the centrally directed, tapering calcificationfree spaces that once housed the inward extensions of the cartilaginous vertebral arches.

In proportions and structure the vertebral centra described here differ considerably from another large variety occasionally found in the Gram clay and probably pertaining to Cetorhinus maximus which is also known from fossil gill-rakers preserved in the clay.

With respect to their general shape, relative proportions and features of calcification the vertebral centra under consideration are apparently closely comparable to large centra reported from the Belgian Upper Miocene deposits and which are believed, probably correctly, to belong to $C$. megalodon (Hasse 1879-85: 228-230; Leriche 1926: 425-427; Casier 1960: 16). Except for their size, they correspond in all significant features to the vertebral centra of extant $C$. carcharias. Given these features it seems reasonable to suppose that the vertebral centra from the Gram locality belong to $C$. megalodon and might be parts of the same fish from which the described tooth derives.

Fig. 2. A-D: Carcharodon megalodon. A: The Gram tooth drawn in labial view to show probable outline and estimated size; approx. xl. B: Outline drawing of similar large tooth (labial view; approx. x 0,3; MGUH VP 3221, ?Miocene, USA) whose semiseparate, slightly protruding left side cusp-portion is shown in (C) labial and (D) lingual views; approx. x1. E-F: Carcharodon carcharias, recent. Tooth from (E) upper and (F) lower jaw of young specimen showing perfectly developed side-cusps (cu); approx. x1; from Zool. Mus. (Copenhagen) spec. nr. 1.B. 1.10.1982 (leg. Brun, Algier), jaws and dentition figured in toto in Bendix-Almgreen 1982b, fig. 2D.

$c u$, lateral cusps; $n t c$, notch, marking off cusp-portion. 


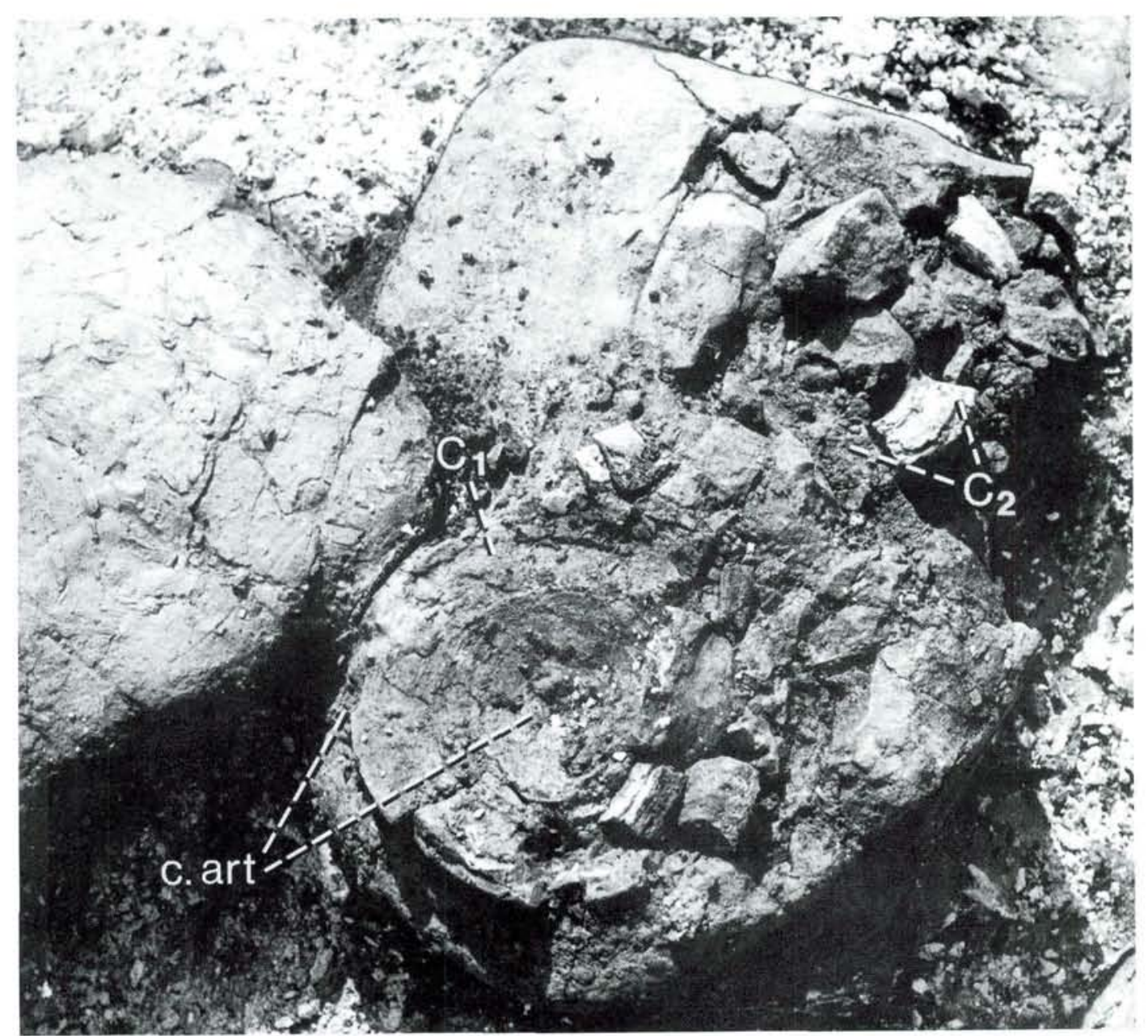

Fig. 3. Two large vertebral centra $\left(C_{1} \& C_{2}\right)$ seen as exposed on the surface of one of the hardened Gram clay nodules found in position in the Gram brick-work clay pit (type loc. of the Gram Formation). Some 20 such centra, probably belonging to Carcharodon megalodon, were preserved detached, but in close proximity in the nodules. Diameter of $\mathrm{C}_{1}$ approx. $23 \mathrm{~cm}$.

c.art, the heavy calcification along the articular surface showing remarkably dense, concentric structure.

\section{Tooth histology and enameloid ultrastructure}

Thin sections were not prepared of the C. megalodon tooth described above, and the histology of its hard tissues was, accordingly, not investigated by means of normal and polarized light microscopy.

However, fracture surfaces of the specimen submerged in alcohol were inspected and photographed (fig. 4B-C) under high power magnification using a binocular microscope. This showed that the composite hard tissue occurring beneath the comparatively thin superficial enameloid layer (i.e. the coronoïn; t.cor, fig. 4A, C) consists of well developed, apparently concentrically laminated denteons originally housing vascular canals (de, fig. 4B), and an interstitial substance (int, fig. 4B) which seems to be somewhat coarse in structure. These features suggest that the composite hard tissue under consideration can hardly be classified as anything else than normal osteodentine (sensu Ørvig 1951, 1967, 1976a) which constitutes the complete interior of the tooth crown. 

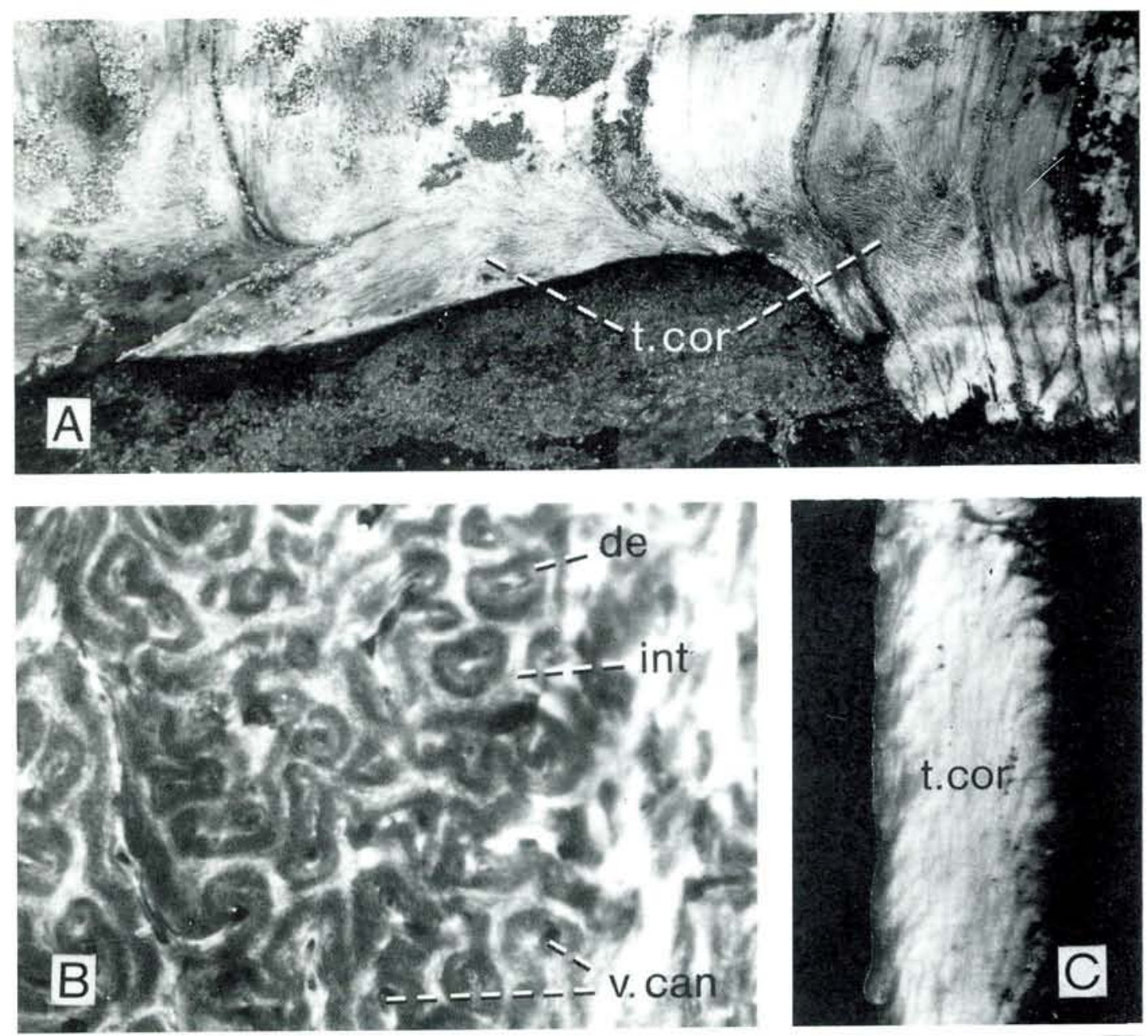

Fig. 4. The Gram Carcharodon megalodon tooth. A: Surface view of structurally perfectly preserved tegmental coronoïn (t.cor) showing indications of the coarse fibrous structure revealed in SEM (compare fig. 5C); approx. x8. B: Fracture surface showing denteons (de) lining vascular canals (v.can) and separated by apparently coarse structured interstitial hard substance (int), a composition indicating that ordinary osteodentine forms the interior of the crown; approx. $x 22$. C: Vertical fracture surface through tegmental coronoìn (t.cor), tooth surface on right side; approx. x22. Photographs taken in alcohol.

Inspection of surfaces features of the enameloid substance (fig. 4A, C) suggested that this was well preserved for SEM investigations. This was confirmed when specimens, prepared and etched with $\mathrm{HCl}$ ( $c f$. Reif 1973; Ørvig 1976a) and then Au-coated by diode "sputtering", were studied in the Scanning electron microscope. The SE micrographs reproduced here depict the ultrastructural texture of the enameloid which is revealed by what Ørvig (1976a) aptly called the fibre-bundle images.

A meaningful evaluation of the findings can be made only in a broad comparative context as done below using information compiled by the writer (Bendix-Almgreen 1982a). The terminology used here also refers to this work and includes the common term under which the enameloid substance is now to be dealt with:

\section{Coronoïn $(=$ elasmobranch tooth enameloid)}

General comments and terminology: The hard substance now under consideration occurs superficially in the $C$. megalodon tooth and in the 

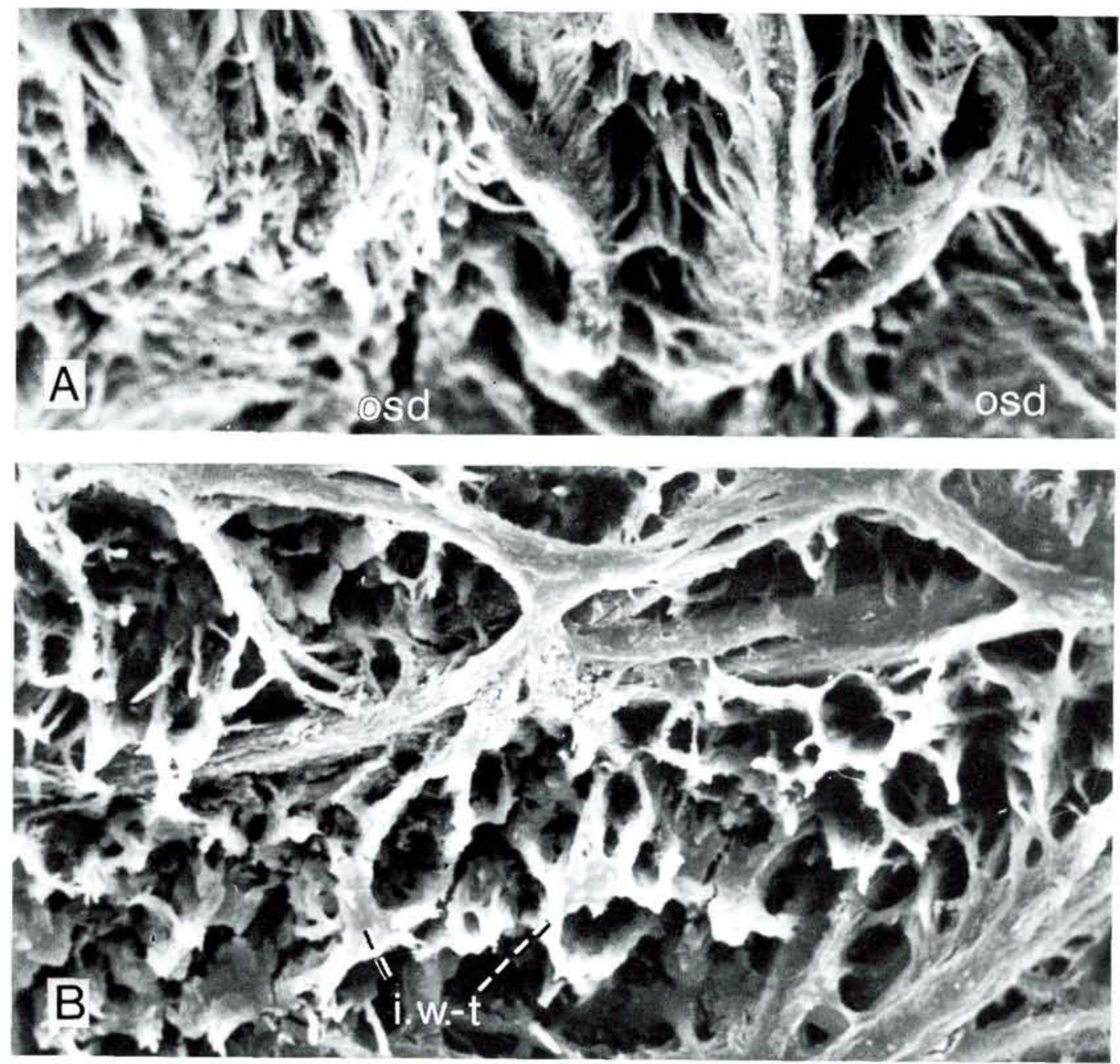

teeth of most other extant and extinct elasmobranchs including bradyodontids (Bendix-Almgreen 1982a). It has been subject to discussion and controversy ever since the times of Owen $(1840-45)$ and other early contributors of the 19 th century.

It has been dealt with under a variety of terms (see e.g. Reif 1973) but, with a few exceptions (e.g. Kjellström 1971), writers nowadays agree that this hard substance by virtue of its optical ultrastructural and histochemical properties can be classified among the hypermineralized hard tissues (Ørvig 1967, 1973, 1976a, b, 1978a, b, 1980b; Bendix-Almgreen 1968, 1975, 1982a;
Reif 1973, 1977, 1978, 1979, 1980; Preuschoft et al. 1974; Goto 1978a, b; and others).

It resembles in some respects those hypermineralized hard substances recently defined under the terms acrodin and pleromin by Ørvig (cf. ref. above), but it can also be distinguished from them by several properties of its own (see below, p. 19).

To acknowledge this, the term coronoin has been introduced for elasmobranch tooth enameloid (Bendix-Almgreen 1982a) and it has been found appropriate to distingusih between tegmental coronï (exemplified here by that covering the crown of the $C$. megalodon tooth; t.cor, 

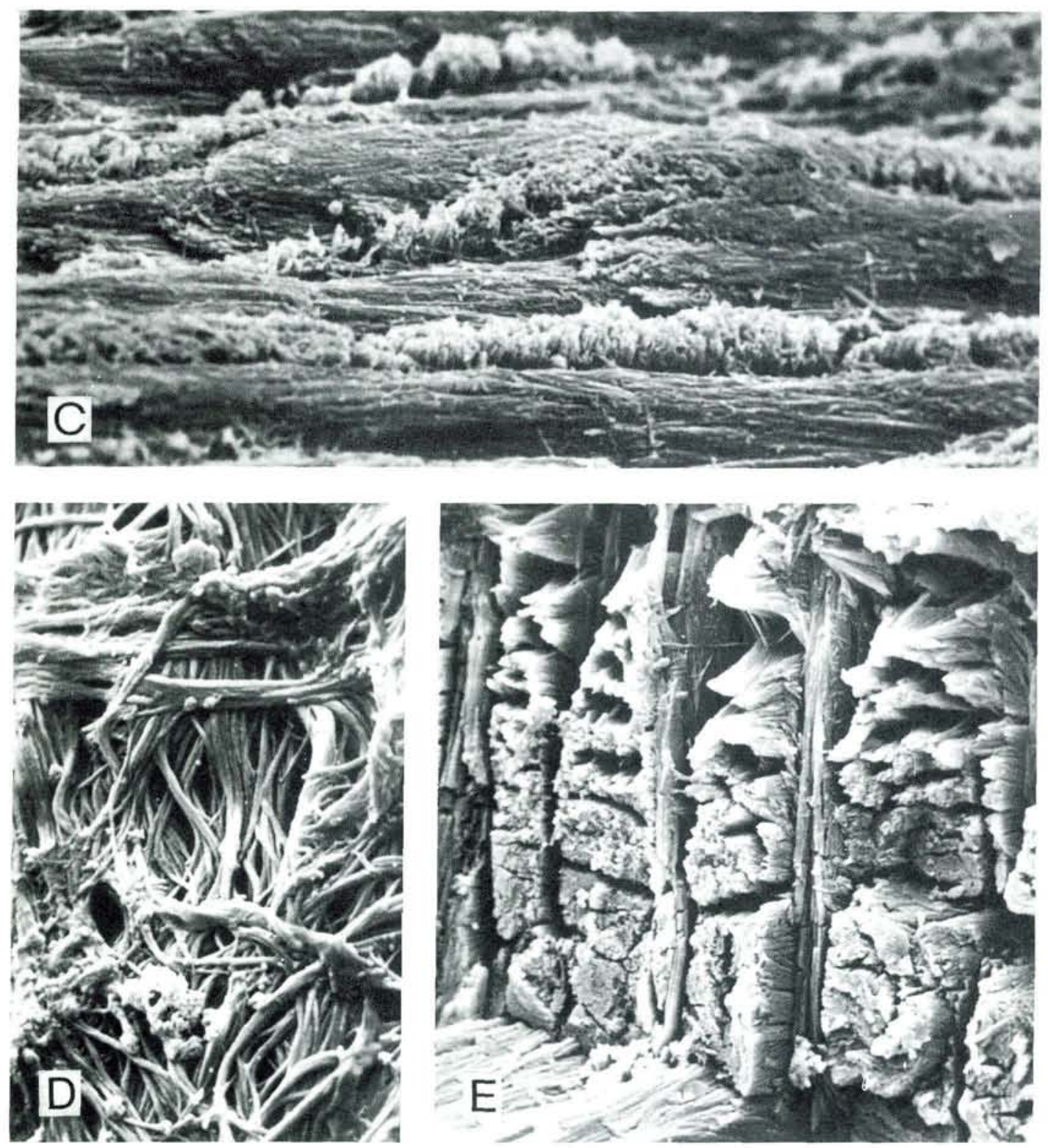

Fig. 5. The Gram Carcharodon megalodon tooth. SEM micrographs of etched tegmental coronoïn. A: Approximately vertical section showing the irregularly woven-textured modification occurring at the jagged boundary towards the osteodentine (osd) below; $\mathrm{x} 720$. B: Slightly oblique section just above the coronoin/osteodentine boundary displaying the transition from the irregularly woven-textured $(i . w .-t)$ to the cross-textured modification above; $x$ 700. C-E: Fibre-bundle images of cross-textured modification at tooth surface (C; x 1800), of same modification in vertical section $(E ; x 1200)$, and of the regularly woven-textured modification (D; $x$ 3100 ) occurring interiorly in the cutting edge denticles.

SEBA scafotek codes: (A) 1:81:962; (B) 1:81:889; (C) $3: 81: 840$; (D) $5: 81: 929$; (E) 2:81:846. 
fig. 4A, C) and vascular coronoïn (present superficially in bradyodontid teeth and tooth plates and in teeth of certain Mesozoic selachians including Ptychodus and Asteracanthus; figs 6A-D, $7 \mathrm{~A}-\mathrm{F}$ ). The latter kind was previously referred to as "coronal pleromic hard tissue" (Ørvig 1967; see also Bendix-Almgreen 1968, 1975; Patterson 1968; Reif 1973) a term now recognized as inappropriate and discarded by Ørvig (1976a: 94, 1978b: 317, 1980b: 234).

Coronoï is always clearly delimited from the dentine underneath, including, of course, that forming the denteons enclosed in vascular coronoin (fig. 7A-F). These two hard tissues (i.e. vascular coronoin and the dentinous tissue of the denteons) combine to form a composite hard substance now recognized by the term decoronoin which replaces the inappropriate "tubular dentine" (Woodward 1921, 1932; Nielsen 1932, 1952; Moy-Thomas 1936a, b, 1939a, b; MoyThomas \& Miles 1971; Patterson 1965; Radinsky 1961). The composite hard substance one is concerned with here, consisting of an enameloid enclosing circumvascular dentinous tissue, cannot possibly qualify as any kind of dentine, nor can that particular hard substance on the basis of which Smith $(1977,1979)$ recently attempted to rehabilitate the old term. - Exit "tubular dentine"!

\section{Coronoin in the SEM}

Fibrous architecture: A classification of coronoïn according to fibrous textures as revealed in the SEM has been made by Reif $(1973,1977,1978$, 1980; in Preuschoft et al. 1974), though the descriptive terminology used by him is not entirely satisfactory. The classification can be refined by using a terminology analogous to that introduced by Ørvig (1978b) for acrodin.

The tegmental coronoïn as developed in $C$. megalodon reveals in the SEM well defined fibrebundle images which according to their distribution patterns can be classified as woven-textured and cross-textured.

Woven-textured coronoïn (corresponding structurally to woven-textured acrodin; Ørvig 1978b) occurs just above the dentine-coronoin junction in the specimen under consideration, where it attains its maximum thickness within the den- ticles studding the cutting tooth edge. Structurally one can (again by analogy to acrodin) distinguish two modifications:

Irregularly woven-textured coronoïn, showing a more or less random arrangement of braided interlacing fibre-bundle images, is found everywhere at the dentine-coronoïn junction (fig. 5A-B). Within the cutting edge denticles such modified coronoïn changes upwards into the regularly woven-textured modification which shows almost straight fibre-bundle images tending to cross each other in a more or less regular network (fig. 5D). These two modifications were collectively referred to by Reif (1973; in Preuschoft $e t$ al. 1974) as "wirrfaseriger "Schmelz" (= "haphazardly fibred", "tanglefibred" and woven enameloid: Reif 1977, 1979).

In the $C$. megalodon tooth, coronoin of the two modifications just mentioned is seen to change upwards into:

Cross-textured coronoïn displaying parallel or subparallel fibre-bundle images arranged orthogonally to each other; some of them are directed longitudinally parallel to the tooth surface, towards which other fibre-bundle images radiate perpendicularly (fig. $5 \mathrm{C}, \mathrm{E}$ ). This particular modification (corresponding structurally to crosstextured acrodin, Ørvig 1978b) constitutes the main part of the coronoin as developed in the tooth under consideration, and in certain places it is structurally coarse enough to render a characteristic pattern discernible on the surface of the specimen under the binocular microscope (fig. 4A).

According to Reif (1973, 1977, 1979; in Preuschoft et al. 1974) the combination of structurally cross-textured and woven-textured coronoïn, described here for $C$. megalodon, is characteristic of the teeth of most extant and extinct euselachians. However, Reif spoke of "parallelfaseriger 'Schmelz"', a category which besides structurally cross-textured coronoïn also included the modification that may be distinguished more appropriately as:

Radial parallel-textured coronoin where all fibre-bundle images (as in the similarly modified acrodin, Ørvig 1978b) maintain an orthogonal direction relative to the tooth surface such as can be observed in the teeth of Ptychodus (r.p.-t, fig. 6A).

Incidentally, the occurrence in Ptychodus teeth 


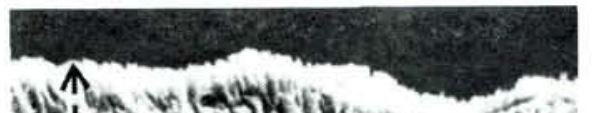

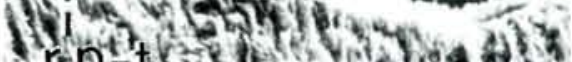
I avinews

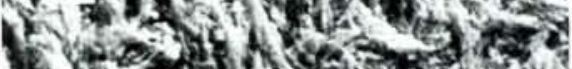

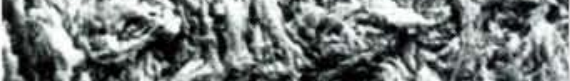
30 on

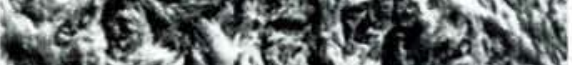
5 (1)

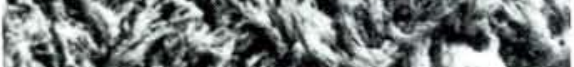

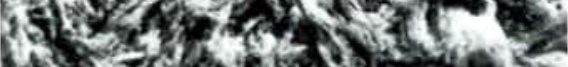
1) 5 .

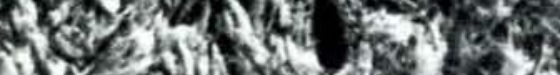
(1)

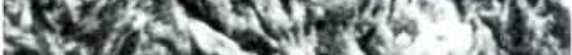
4. A

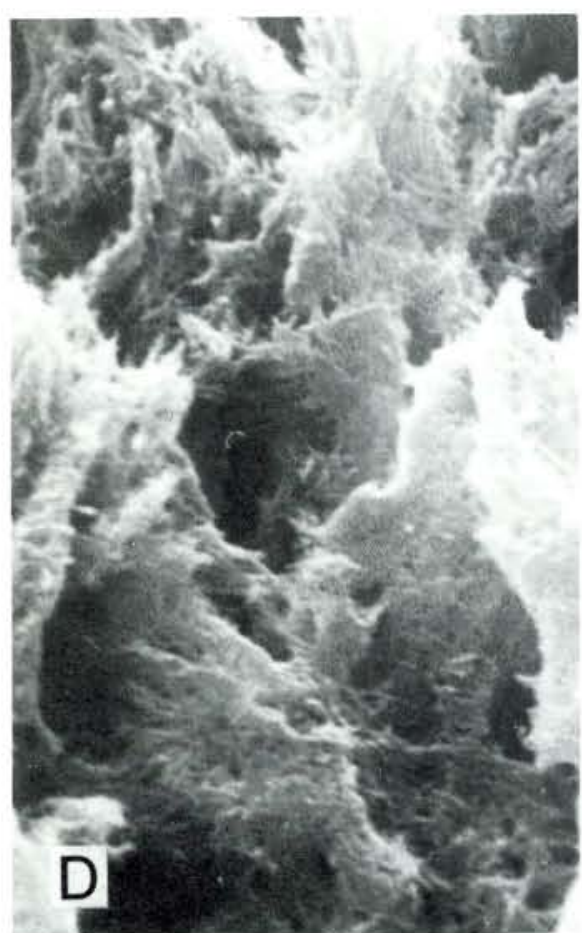

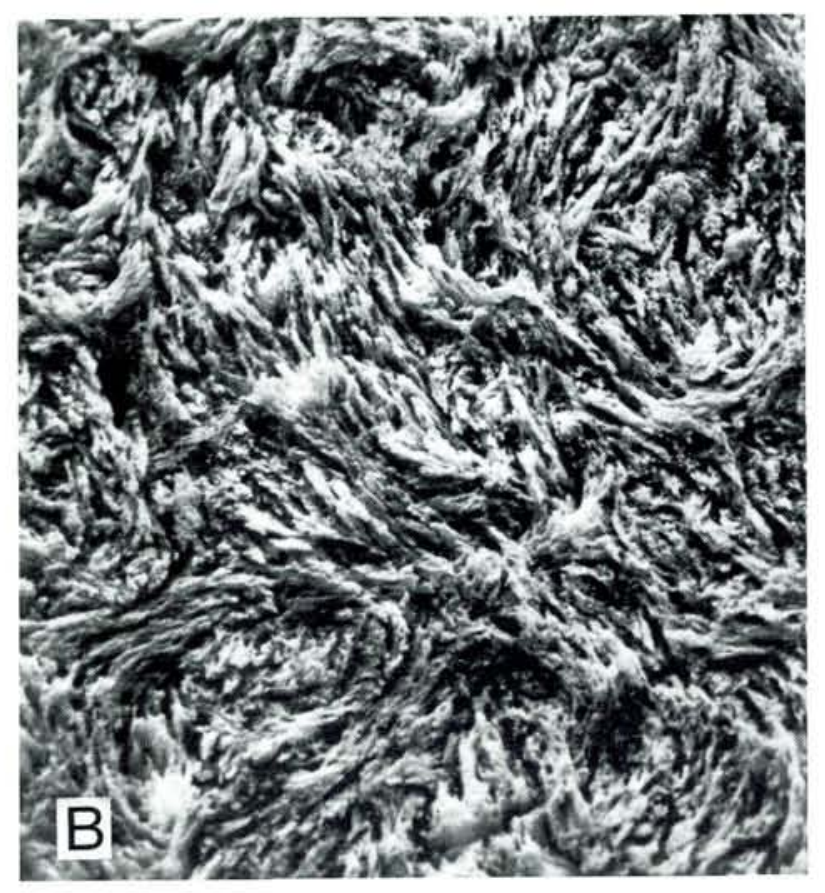

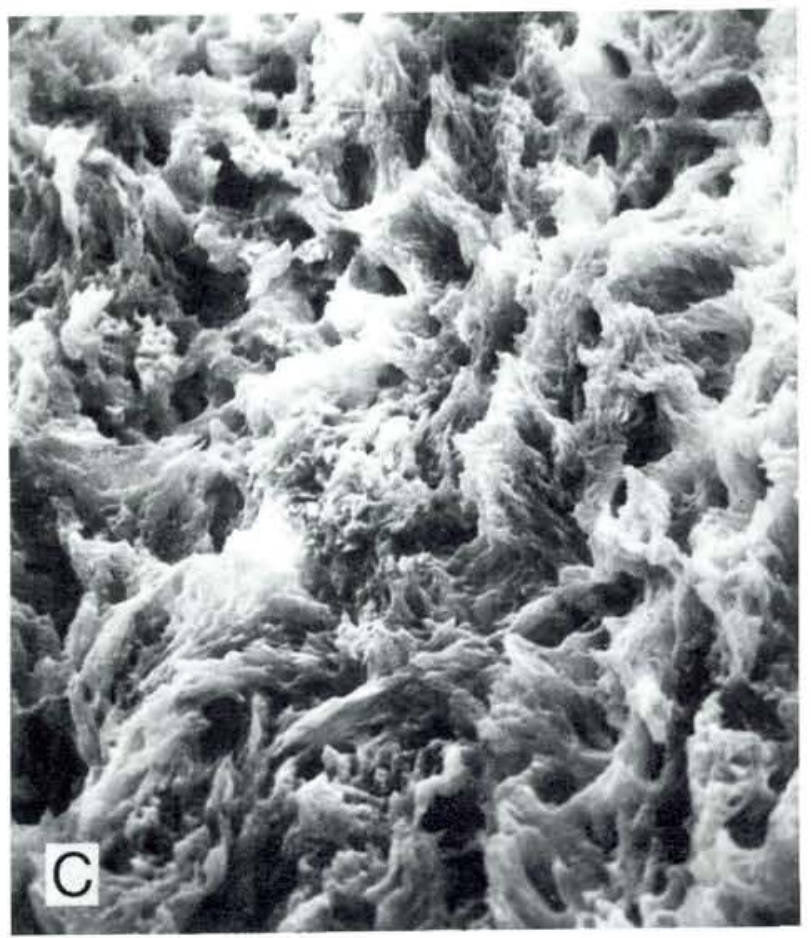

Fig. 6. A-B: Ptychodus latissimus, Cretaceous, England. C: Asteracanthus subreticulatus, Upper Jurassic, England. D: Asteracanthus ornitissimus, Upper Jurassic, England. SEM micrographs of etched vascular coronoin; vertical sections. A-B: Fibre-bundle images of the irregularly woven-textured modification changing into the radial parallel-textured one $(r . p .-t)$ towards the surface $(\mathrm{A}, \mathrm{x} 345)$, and of the former modification in higher magnification (B, x 575). C-D: Fibre-bundle images in irregularly woven-textured arrangement; magnification: C x 1100; D x 5000 .

SEBA scafotek codes: (A) 73:75:221; (B) 73:75:208; (C) 55:75:152; (D) 61:75:179. 

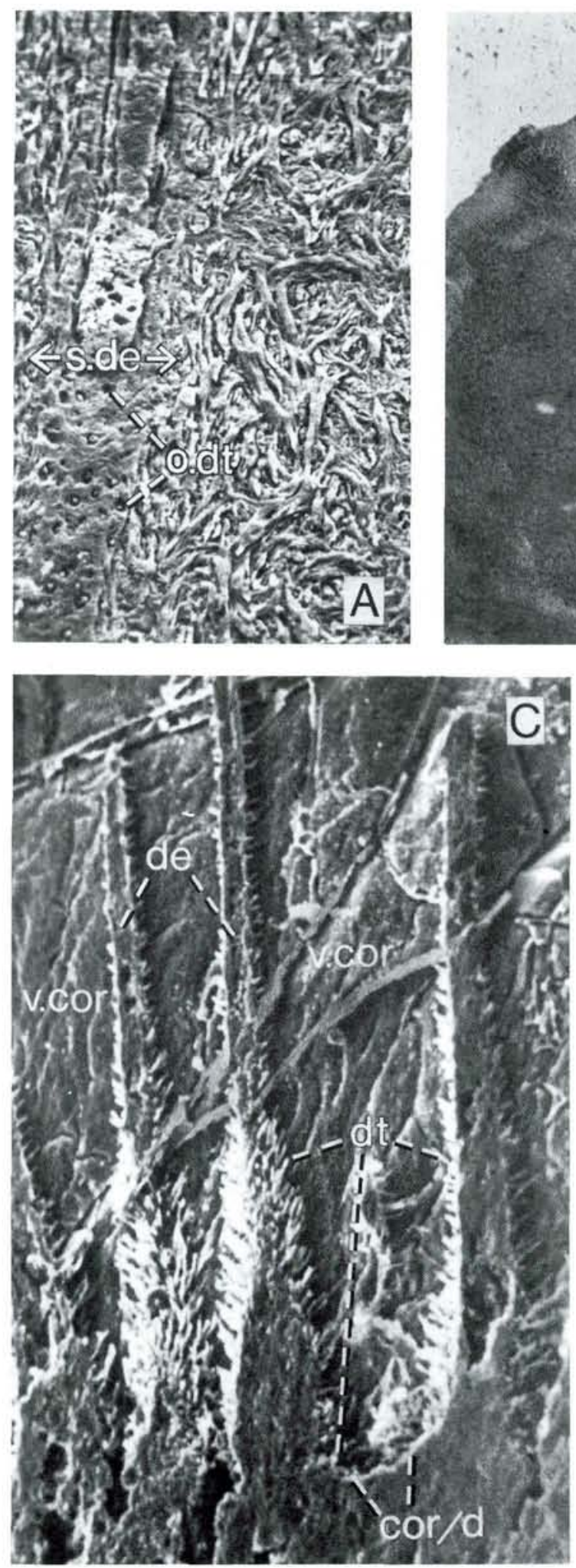
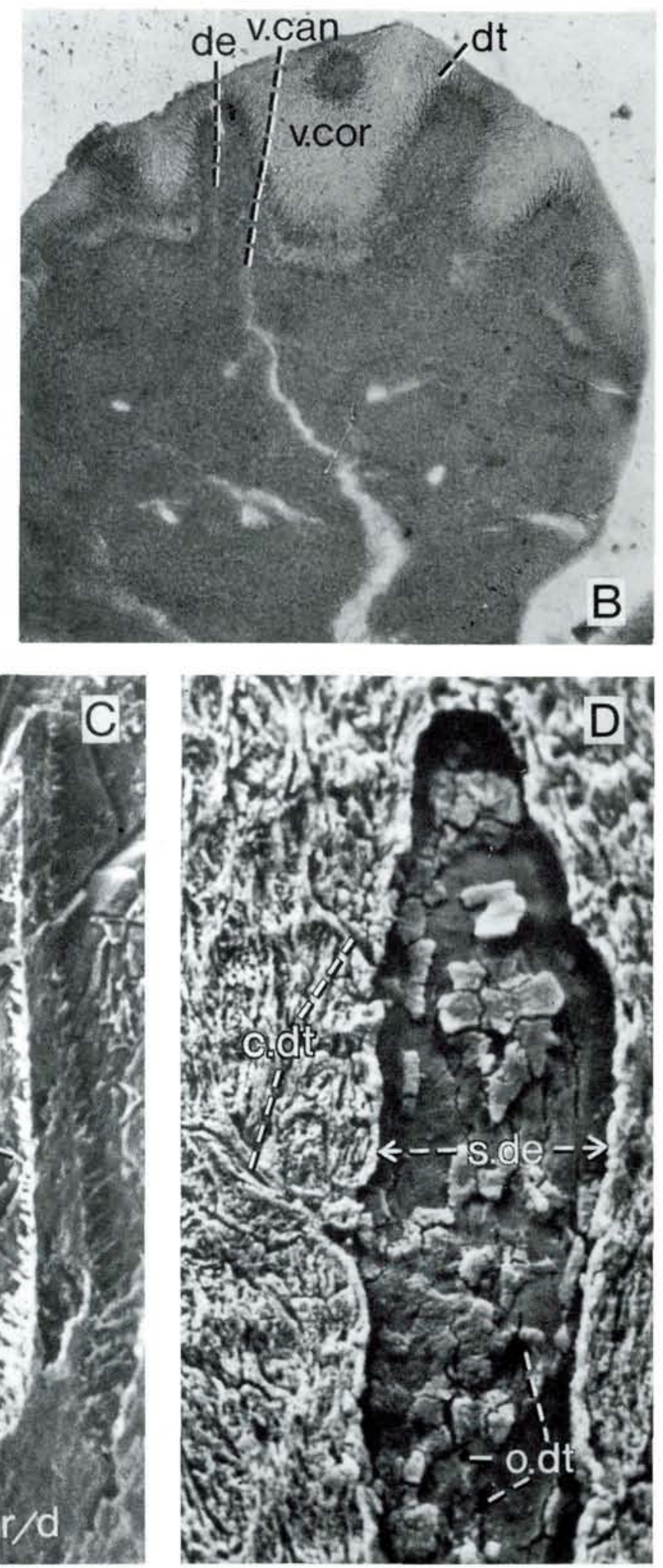

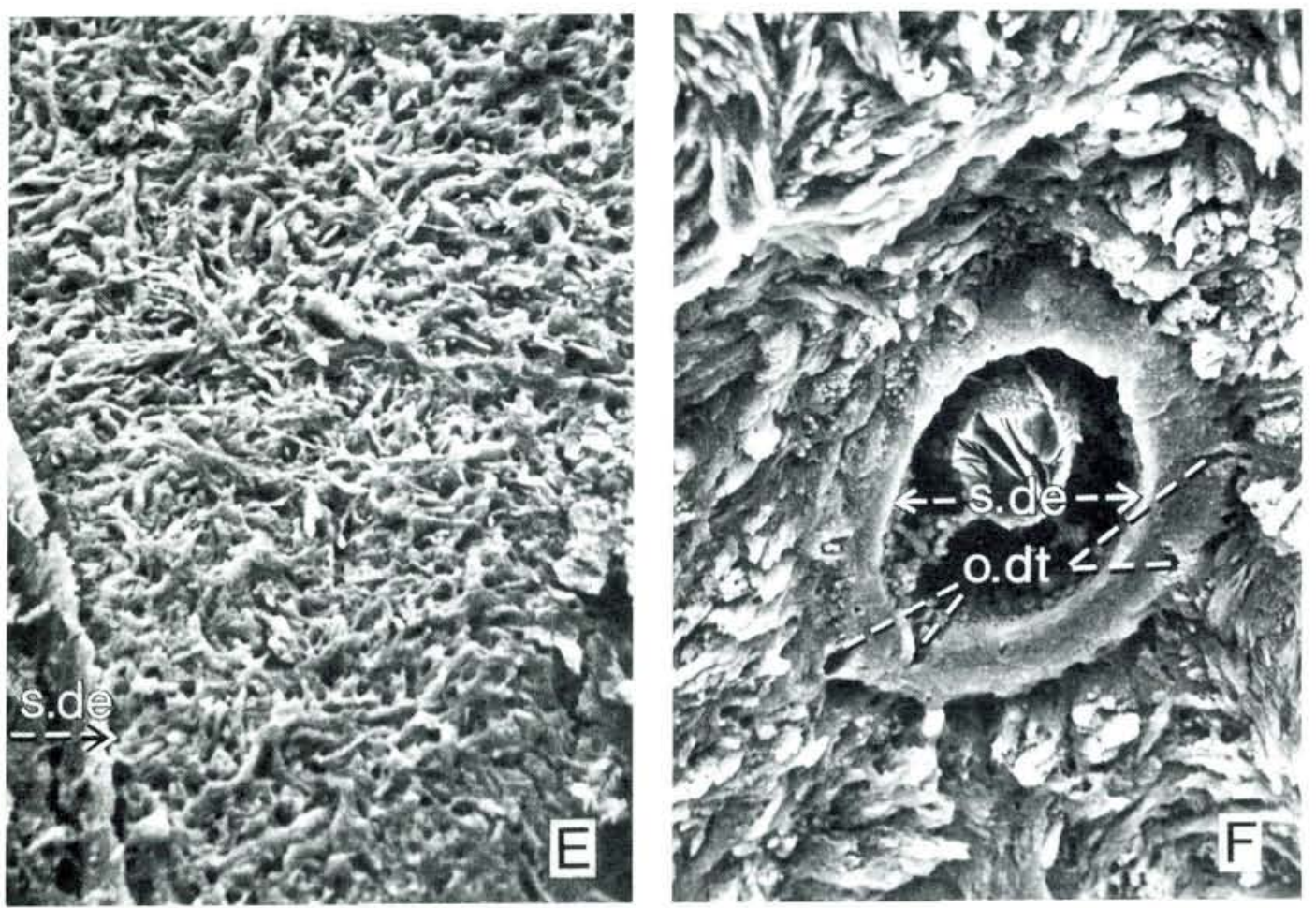

Fig. 7. SEM and optical micrographs to show vascular coronoin, its relation to enclosed denteons and dentinal tubules, and to the dentine of the tooth base in dental units of: (A) Psephodus magnus, Lower Carboniferous, Ireland, etched material in vertical section, x 190; (B) Erikodus groenlandicus, Upper Permian, East Greenland, MGUH VP 57, vertical section of unworn tooth in normal light, $x$ 56; (C) Undetermined cochliodontid, Perm-Carboniferous, Muth NW India, etched material (dentinous tissues silicified) in vertical section, x 100; (D) Ptychodus latissimus, Cretaceous, England, etched material in vertical section, x 510; (E) Psammodus rugosus, Lower Carboniferous, Ireland, etched material in vertical section, x 285; (F) Psephodus magnus, Lower Carboniferous, Ireland, etched material in roughly horizontal section, $\mathrm{x} 490$.

SEBA scafotek codes: (A) TØ 92:117; (C) 14:75:10; (D) 73:75:911; (E) TØ 93:135; (F) TØ 92:125.

$c . d t$, canals for dentinal tubulus; cor/d, coronoin / osteodentine boundary; de, denteons; $d t$, dential tubules; o.dt, funnel-shaped openings of canals for dentinal tubules; s.de, space occupied by denteon now removed by etching; v.can, vascular canals; v.cor, vascular coronoïn.

of a zone of radial parallel-textured coronoïn, superficially to the otherwise irregularly woventextured modification forming most of the vascular coronoïn here (figs 6A-B, 7D), shows up conspicuosly in thin sections both in normal and polarized light. It is this condition which led workers to believe that a special kind of hard tissue (pallial dentine, Radinsky 1961; Patterson 1965, 1968; Bendix-Almgreen 1968; Ørvig 1976a), significantly different from that below, capped the teeth in Ptychodus and set them apart histologically from those of bradyodontids. This, it is now clear, is not the case.
It may be added in the present context that SEM survey of bradyodontid tooth material (e.g. Psammodus rugosus, Psephodus magnus, fig. 7A, E-F) and teeth of the durophagous selachian Asteracanthus (fig. 6C-D) showed that the vascular coronoïn in these forms is irregularly woventextured throughout, but that in some cases (e.g. Psephodus magnus, fig. $7 \mathrm{~F}$ ) it tends to form a dense almost compact zone just peripherally to the enclosed denteons.

The latter special condition is of little importance at this point. The issue here concerns the fact that coronoin includes varieties which are 
equivalents of those sorts of acrodin that according to Ørvig (1978a, b) are (1) irregularly woven-textured throughout and (2) woven-textured changing into radial parallel-textured towards the top. Thus coronoin includes structural equivalents of every sort of acrodin so far recorded from the teeth of non-teleostean (Ørvig 1978a, b) and teleostean (Shellis \& Berkovitz 1976; Reif 1979) actinopterygians.

In addition there is that special sort of coronoin which Reif (1973, 1977, 1978, 1979, 1980; in Preuschoft et al. 1974) referred to as "einzelkristallit "Schmelz"" (= "single-crystallite "enamel"') and which seems to have no direct equivalent among known kinds of acrodin (cf. Ørvig 1978b: 313). Coronoïn of this sort is, according to the writer's investigations, also present in the teeth of the petalodontid Janassa and in certain Helodus-like teeth from the Devonian. It is here composed of minute vermiform to rod-like structures, more or less randomly arranged and corresponding apparently to what Reif (cit. op.) interpreted as single crystallites. It is, however, difficult to decide what these structures really represent. Neither in shape nor in range of size do they seem to resemble closely the fluor-apatite crystallites which were recently described by Daculsi \& Kerebel (1980) from TEM micrographs of cross-textured coronoin in the teeth of extant Carcharhinus leucas. They could be aggregates of crystallites in which case they might represent images of separate collagen fibres which were parts of a lowly organized precoronoïn matrix (see below: p. 19). Fibre-images of originally separate collagen-fibres are displayed by the pleromin of some ptyctodonts (Ørvig 1980b), but resemblance to the structures considered here is remote. An interpretation of the latter as separate fibre-images, however, appears to agree with their arrangement in specific textural patterns: "either randomly orientated or more or less perpendicular or more or less parallel to the tooth surface" (Reif 1979: 548). These remarks indicate why the writer cannot fully accept Reif's interpretation; it is only for practical purposes that the term "single-crystallite" coronoin is adopted here.

\section{Remarks on other hard tissues and microstructures of elasmobranch teeth}

The SEM investigated C.megalodon samples preserved no traces of the thin cuticle ("Glansschicht", "shiny layer", and other terms; see e.g. Reif 1973, 1977; in Preuschoft et al. 1974) generally present superficially to the tegmental coronoï in euselachian teeth. This cuticle presumably forms by mineralization of the basement membrane (Schmidt 1958) which surrounds the individual tooth primordia and upwards adjoins the inner dental epithelium (i.d.e) cells of the epidermis. Its absence in the samples here is no doubt secondary and due either to preservation circumstances or to the preparation of the samples for SEM.

The distinct, though jagged, boundary between coronoïn and the dentine underneath was clearly revealed in the SEM, but the structure of the latter hard tissue is poorly exhibited (osd, fig. 5A) due to the methods of preparation. It is well known from optical microscopy that coronoïn and dentine never merge into, but are easily distinguishable from, each other at the junction. The feature is clearly illustrated by SEM micrographs of tegmental coronoïn figured by e.g. Reif (1973, 1979) and it can now be demonstrated also from SEM investigation of vascular coronoïn (cor/d, fig. 7C).

The relation between the dentinal tubules and the tegmental coronoïn in $C$. megalodon could not be ascertained from any of the SEM investigated samples. However, the species shows the normal arrangement for euselachian material: the dentinal tubules, extending roughly vertically upwards from the dentine, penetrate into the tegmental coronoin for some distance towards the surface (cf. e.g. Agassiz 1836, Pl. Q: 1-2). Exactly similar conditions are shown by those dentinal tubules which extend into the vascular coronoï from the top of the enclosed ascending denteons and from the dentine of the base. Only those dentinal tubules which pierce the vertical walls of the denteons maintain an oblique direction outwards and upwards towards the surface of the tooth (dt, fig. 7B-C). This topographical variation is of no consequence here where the crucial issue concerns the relations of the dentinal tubules or, more precisely, those of the sclero- 
blasts once housed in them with their superficially directed processes. The relations between these, the vascular coronoin and the underlying dentine correspond to that displayed in recent material between the odontoblasts, the mature tegmental coronoin and the underlying dentine. This indicates that the scleroblasts once active in the early ontogenetic phases of vascular coronoïn formation acted principally like those in the corresponding formative phases of recent tegmental coronoïn.

\section{Comparison with other tooth enameloids}

Functionally coronoïn corresponds, of course, to other tooth enameloids including acrodin and pleromin which it resembles ultrastructurally and, in some respects, histologically.

Among the pleromins, particularly, the modification referred to by Ørvig (1976a) as vascular pleromin, which occurs in a variety of dipnoan tooth plates, has been considered at various occasions in conjunction with vascular coronoïn because of their similarity in certain histological features: both contain denteon-lined, superficially ascending vascular canals.

However, dipnoan pleromin like other sorts of pleromin (those occurring in the statodont dentitions of ptyctodontids and chimaeroids or that of the compact pleromo-aspidin encountered in the dermal skeleton of psammosteid heterostracans) are all characterized by a wide range of specific properties (Ørvig 1967, 1976a, b, 1980a, b). Among these, peculiarities related to the ontogenetic formation and growth notably distinguish the pleromins from other kinds of hypermineralized hard substance including coronoïn, and place the pleromins in a unique category.

The similarity in histological composition which Ørvig (1976a) maintained - reasonably enough on the knowledge available then - should exist between the steeth" of the Devonian dipnoan Griphognathus and those of bradyodontids and certain selachians (e.g. Ptychodus) is now seen to be merely superficial. The Griphognathus teeth are, according to Ørvig (1976a: 94), composed histologically of a superficial layer of enameloid followed interiorly by one of pallial dentine and then a hypermineralized hard substance containing vertical denteons. This histological arrangement has no direct equivalent in the teeth of the elasmobranchs just referred to above. In these, the crowns exclusively consist (except for the occasionally discernible thin external cuticle: the mineralized basement membrane) of vascular coronoï from top to bottom (see above, p. 12-15). Moreover, the ultrastructural texture of this vascular coronoin is definitely different from that of the hypermineralized interstitial hard substance in Griphognathus (compare present paper figs 6A-D, 7A, D-E and figs 31-32 in Ørvig 1976a).

The conditions of the Griphognathus "teeth" are interesting in other contexts (e.g. the derivation and nature of the hard tissue sheet developing superficially in dipnoan tooth plates early in ontogeny), but they are seen to be irrelevant to the coronoin considered here.

Before leaving the pleromin/coronoin comparison, one should add that the relations found in the chimaeroid tooth-plates between the columns of pleromin and the osteodentine forming the enclosing scaffold-like structure are so entirely different from those exhibited by vascular coronoin relative to the osteodentine of the tooth base in the dentitions of bradyodontids that these diverging features alone-suffice to eliminate the possibility that the statodont chimaeroid dentitions have evolved phyletically from the lyodont dentition of any known bradyodontid (fig. 8; see also Jaekel 1901; Regan 1910). This point has been discussed in detail elsewhere (Bendix-Almgreen 1982a), but it may be mentioned that the evidence from histology and characters of the dentition in the two groups tally perfectly with the writer's earlier conclusions (Bendix-Almgreen 1968,1971$)$ maintaining contrary to opinions held by other workers (e.g. Dollo 1907; Woodward 1921, 1932; Moy-Thomas 1935, 1936a, b 1939 a, b; Moy-Thomas \& Miles 1971; Patterson 1965, 1968; Obruchev 1967; Lund 1977a, b; Miles \& Young 1977; Schaeffer \& Williams 1977) that the phyletic ancestors of the chimaeroids, whatever they were, have to be searched for elsewhere than among the bradyodontids or among any other lyodontid elasmobranchs including the peculiar iniopterygians (Zangerl 1973; Zangerl \& Case 1973; Stahl 1974, 1980). 


\section{STATODONT}

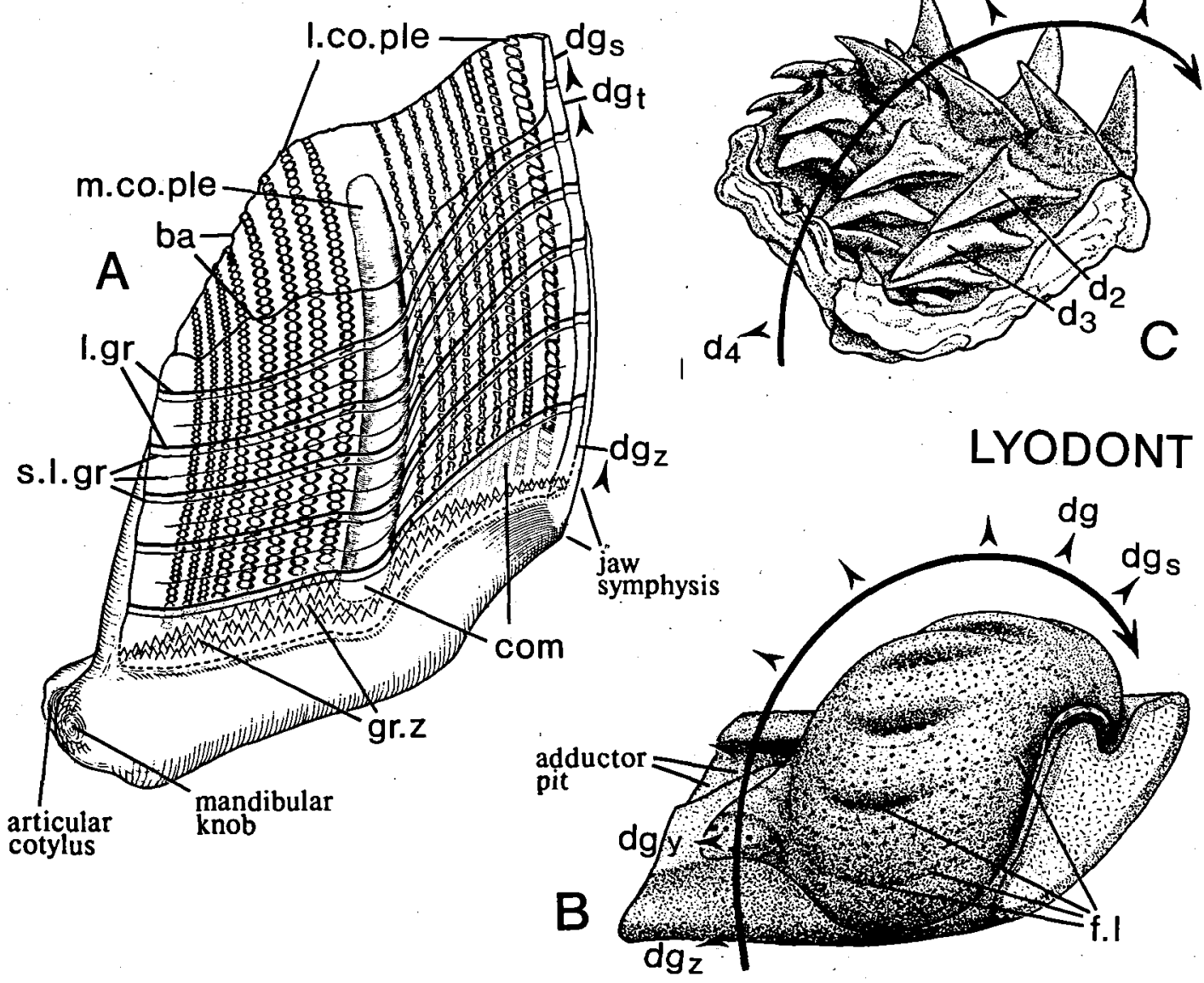

Fig. 8. Cochliodontid and chimaeroid tooth plates, their organization and bearing on the phylogenetic issue. Summary illustrated by drawings of: A: Chimaerid tooth plate (Chimaera monstrosa, recent, left lower jaw and t.pl., the latter schematically drawn from stereoscopic radiographs; approx. x 3,3). B: Cochliodontid tooth plate (Deltodus concha, U. Carb. (Myachkovian), U.S.S.R., posterior left lower t.pl. (approx. $x$ 5,5) restored in position on jaw-section according to conditions shown by an almost complete lower jaw and dentition of another cochliodontid: Pleroplax rankinei). C: Part of lower jaw and dentition of recent selachian: Carcharhinus falciformis; approx. x 1,5. Specimens shown in oblique medial view.

The chimaeroid tooth plate (A), being of the statodont kind, grows throughout life continuously in the basal direction. The growth takes place along the entire basal side (gr.z) where new dental material continues to form and becomes added, effectuating the tooth plate's age-correlated increase in size and compensating also for the constant loss of dental material superficially from abrasion on the biting area $(b a)$. During subsequent growth by adding new material basally, the just previously formed material undergoes further ontogenetic development and emerges, in the species under consideration, ultimately as a bone-like hard substance (instead of osteodentine as in most other species; cf. Ørvig 1976a) constituting the extensive scaffold-like structure which encloses the tritural columns (l.co.ple, m.co.ple) consisting of the hypermineralized pleromin. This, too, is under ontogenetic formation in the lower part of the tooth plate where compartments (com) occupied by prepleromin are shown as disclosed by the radiographs. To show in their entirety the beadstring like laterad pleromin columns (l.co.ple) and the medial rod-shaped one (m.co.ple) extending vertically from the biting area $(b a)$ downwards towards the base, and their relation to the scaffold-like structure, the hard substance of this and the external thin enameloid sheet are depicted "transparent" and featureless except for the growth lines (l.gr, s.l.gr) shown here on the medial and adsymphysial sides but, for clarity, omitted on the lateral one. According to the features now considered, this kind of tooth plate forms and grows continuously by fusion in the vertical direction between consecutive generations of dental material $\left(d g_{s} d g_{t}-\right.$ $d g_{z}$ ) each occupying a horizontal position and developing basally to the preceding one (cf. arrow-heads); these conditions are reflected among others by the parallel course of the growth lines, in particular by the distinctly marked off primary ones (l.gr).

The cochliodontid tooth plate (B), now under consideration, is an entirely different kind of compound dental structure. It has well defined coronal and basal parts (consisting, respectively, of vascular coronoïn enclosing occlusally directed denteons, and of normal osteodentine adjoined beneath by a layer of laminated bone-like hard tissue), and it is a laterally growing structure, increasing in size by periodic apposition at the lingual side of successive generations of dental material $\left(d g_{y}, d g_{z}\right)$. Each new generation $\left(d g_{z}\right)$ develops during ontogeny into coronal and basal portions which fuse laterally with the corresponding ones of the preceding generation $\left(d g_{y}\right)$. Fusion lines, often appearing more or less groove-shaped $(f . l)$, mark off the boundaries between consecutively developed dental 
Turning now to the topic of how to distinguish coronoin from the acrodin of actinopterygian dentitions, the writer concurs with Ørvig (1978c: 317) who concluded that such a distinction has to be based at present on structural features.

No doubt coronoïn and acrodin show more resemblance to each other than to any other enameloid including ganoin which even ultrastructurally is entirely different (cf. Ørvig 1978a, c). Coronoïn, like acrodin, always occupies a superficial position in the teeth, is clearly separable from the underlying dentine and contains dentinal tubules (= acrodin canals of type A: Ørvig 1978c). However, coronoïn can be structurally distinguished from acrodin by the following: (a) coronoïn may contain denteon-lined vascular canals ascending roughly vertically towards the tooth surface; (b) it generally lacks residual spaces of the tube-like type often found in acrodin (= acrodin canals of type B: Ørvig 1978c) and it possesses nothing like the canals that often penetrate acrodin from its outer surface ( $=$ acrodin canals of type C: Ørvig 1978c); (c) coronoïn shows a greater variety of fibrous architecture including the 'single-crystallite' categories which are unmatched in acroding; (d) coronoïn varies in the thickness to which it may be developed (extremely thin in batoid teeth; moderately thick in e.g. the teeth of euselachians; and reaching considerable thickness in bradyodontid and certain selachian teeth equipped with the vascular coro- noïn sort); and (e) it does not occur in association with any other kind of enameloid (in contrast to the acrodin-ganoin association often seen in actinopterygian teeth: Ørvig 1973, 1978a, c).

\section{Coronoïn ontogeny and relationship to acrodin}

The ultrastructural fibrous architecture of the coronoïn of, e.g., the $C$. megalodon tooth (fig. $5 \mathrm{~A}-\mathrm{E}$ ) is now recognized from the study of recent shark tooth material to reflect in detail the distribution and arrangement of the collagen fibrills originally present in the organic matrix - the precoronoin - from which coronoïn forms ontogenetically (Scmidt \& Keil 1958; Garant 1970; Ripa et al. 1972; Kemp \& Park 1974; Kerebel \& Daculsi 1975; Goto 1976, 1978b; Daculsi \& Kerebel 1980).

The precoronoin located beneath the basement membrane which is adjoined superficially by the i.e.d. (inner dental epithelium) cells of the epidermis, is of ectomesenchymal derivation (Kvam 1946, 1950; Kerr 1955; Poole 1956, 1967, 1971; Garant 1970; Kemp \& Park 1974; Kerebel \& Daculsi 1975; Goto 1976, 1978b) and is rich in collagen. Its formation seems to be closely connected with the activity of those scleroblasts which subsequently participate as proper odontoblasts in the formation of dentine underneath

generations ( $d g_{s}, d g_{t}-d g_{y}, d g_{z}$ ) which occupy positions beside each other (cf. arrow-heads) in a linguo-labially extending series across. the jaw exactly as the teeth of the transverse tooth rows on the jaws of both selachians (C: $\left.d, d_{1}-d_{4}\right)$ and batoids. Patterns of wear marks and certain features of the base (observed in many cochliodontid tooth plates, including those of the species figured, but omitted in this drawing) indicate that these tooth plates, as they grew periodically also changed position (large arrow) towards the side of the jaw: periodic growth and change in position across the jaw were parts of the same rhythmic process by which these tooth plate retained maximum biting and grinding efficiency while their undiscardable older and worn parts became incoiled at the labial side of the jaw. Accordingly, these tooth plates possess basically the same sort of tooth replacement mechanism as that by which teeth are replaced in selachian ( $\mathrm{C}$ : large arrow) and batoid dentitions. Various material, including articulated dentitions, shows that the features now described are characteristic for all parts of the cochliodontid dentition. There is, moreover, evidence to show that the mass of dental material, added to the tooth plate during each growth stage $\left(d g_{d}-d g_{z}\right)$, in fact corresponds to several teeth which, situated side by side, failed to individualize during ontogeny, and formed in continuity with each other. Consequently, the cochliodontid tooth plate can be interpreted as a fusion-product comprising teeth of several transverse tooth rows which occupy positions relative to each other and to the jaw exactly like those constituting the selachian dentition (C). From the above remarks it should be clear enough that the cochliodontid dentition, although specialized in many respects, nevertheless corresponds in all essential features with the dentitions of selachians (C) and batoids and is, accordingly, of the lyodont kind. The same is, incidentally, true of the dentitions of all other known bradyodonts.

The chimaeroid dentition, composed of tooth plates of the statodont kind (non-replaced dental structures with their special manner of growth and that peculiar relationship shown by their hard tissue constituents), is of an entirely different nature than , and cannot possibly have evolved during phylogeny from, any dentition of the lyodont kind. Consequently the codhliodontids may, like all other bradyodonts, by virtue of their dentition rather conclusively be dismissed as possible phyletic ancestors of the chimaeroids. As a whole the bradyodonts may, on the other hand, by way of the same evidence be regarded as close relatives of the selachians (s.l.) although the more precise nature of this phylogenetic relationship so far remains unknown. 
the coronoin (Poole 1956; Ørvig 1967) and whose long trailing, superficially directed processes become enclosed in the dentinal tubules contained in the mature coronoïn.

With respect to the complex sequence of histogenetic processes by which coronoïn forms out of the precoronoin, there is evidence suggesting that they largely depend on activities by the i.e.d. cells ( $=$ the ameloblasts of, e.g., Kemp \& Park 1974; Kerebel et al. 1977; Moss 1977) which probably secrete proteins that contribute to the degradation of the collagens making them ready for removal prior to mineralization and subsequent hypermineralization. Apparently, the i.d.e. cells also provide mineral constituents (Kemp \& Park 1974; Kerebel et al. 1977; Goto 1976, 1978b) and perhaps participate by some sorts of resorption activity in the removal of degraded organic constituents, including collagens, of the precoronoïn.

In the ultimate structure, mature coronoin is like other hypermineralized hard substances characterized by its negligible content of organic matter including collagen (Kerebel \& Daculsi 1975; Goto 1978a, b). Its mineral constituent, mainly fluor-apatite, occurs in the form of minute crystallites (found to be elongated hexagonal in Triakis scyllia and Carcharias leucas: Goto 1978b; Daculsi \& Kerebel 1980) reflecting the orientation of the original collagen fibre-bundles, in alignment with which the initially formed crystallites are laid down. This same orientation is, for reasons still unexplained, subsequently retained by all crystallites developing (when virtually all collagen has gone) during further mineralization and subsequent hypermineralization. The crystallites make up the characteristic fibrebundle images that can be observed also in fossil coronoïn (figs 5A-E, 6A-D, 7A, D-F; see also Reif 1973, 1977, 1978, 1979, 1980a).

The close similarity in ultrastructure and all essential histological features between recent and fossil coronoï (including the vascular variety, see above p. 12) suggests that the latter largely developed ontogenetically and histogenetically by processes like those just ountlined for recent material.

What has been summarized concerning coronoï ontogeny and histogenesis may, according to the evidence so far available, equally well apply to the acrodin of actinopterygians (see e.g. Kvam
1946, 1950; Kerr 1960; Ørvig 1967, 1973; 1978a, c; Poole 1967; Herold 1974; Shellis \& Miles 1974, 1976; Shellis 1975; Shellis \& Berkovitz 1976). Indeed, it has been maintained by Reif (1979: 547-548) "that the enameloid of sharks is formed in the same way as the enameloid of teleosts. This similarity of hard tissue formation is probably not due to convergence between teleosts and sharks, but to common ancestry".

However, coronoïn and acrodin belong individually to two groups which separated phylogenetically far back into the Palaeozoic. Thus actinopterygians were evidently in existence in Silurian times (Gross 1968, 1969, 1971; Janvier 1971, 1978) and elasmobranchs, now known from the Lower Devonian and the Silurian (Thorsteinsson 1973; Mark-Kurik 1975), might have been in existence already in the Ordovician, judging from those vertebrate remains (some very reminiscent of teeth and scales of early selachians) which Moskalenko (1970: Pls 2; 3: 4-6; 4: 1a-c; 5: 5-6) erroneously referred to the conodonts.

Some sort of coronoïn is apparently developed in the Phoebodus politus, Protacrodus sp. and 'Cladodus' sp. teeth (Gross 1973) from the late Lower Famennian Maple Mill shale of Iowa (Klapper et al. 1971). These deposits also yielded some Helodus-like teeth which, according to the writer's investigation of thin sections and SEM samples, present the geologically earliest, unequivocal evidence for the presence of vascular coronoïn. This shows, however, an ultrastructure reminiscent of the 'single-crystallite' coronoin in, e.g., the Carboniferous Dicrenodus (Reif 1978, fig. $7 \mathrm{c}$ ) and differs in this respect entirely from the vascular coronoïn of various Lower Carboniferous bradyodontids including Psephodus magnus and Psammodus rugosus noted above (p. 12, fig. 7A, E-F).

Acrodin is, according to Ørvig (1978c: 307), present in palaeonisciform teeth from the Upper Carboniferous but is unknown in older material. At least in Lophosteus superbus of the late Silurian (Gross 1971) it is apparently absent.

There are, consequently, no means to decide whether the two enameloids under consideration are equally old phylogenetically or whether they resemble each other in geologically early elasmobranchs and actinopterygians. 
Accordingly, the fossil record neither supports nor rejctes Reif's (1979) assumption concerning a common origin for coronoïn and acrodin from some ancestral enameloid type.

On the other hand, it is evident that even if coronoin and acrodin were equally old in phylogeney they have evolved separately for a long time during which they both underwent evolutionary changes. For coronoin this lead to the multitextured conditions which, according to Reif $(1977,1978,1979,1980 a)$, are particularly characteristic for euselachian tegmental coronoïn. There is, moreover, evidence to show that both the enameloids under consideration, already by Mesozoic times, had acquired the various structural features by which they can be distinguished from each other. At least some of these structural features suggest that the ontogenetical and histogenetical processes by which coronoïn and acrodin develop in recent material can hardly be so similar as one may be led to believe from published information. We are, after all, concerned with complex cytological and histochemical processes and our grasp of these is certainly imperfect at present.

The apparent similarity in ontogenetical formation between coronoïn and acrodin of recent material is, in these circumstances, hardly tenable as evidence for the common phylogenetic origin, assumed by Reif (1979) for these two enameloids. The hypothesis certainly deserves consideration but, at present, it suffers from lack of unambiguous evidence.

It may be possible at some future date, when the processes of ontogeny and histogenesis are better known, to distinguish coronoïn from acrodin also on the basis of special developmental features whose presence is apparently suggested by the structural characteristics on which the distinction between these two enameloids now rests.

\section{Tegmental coronoïn in euselachian taxonomy}

Returning, finally, to the tegmental coronoïn of the investigated $C$. megalodon tooth the writer was impressed by the close similarity between its SEM-revealed fibrous architecture and that of extant C. carcharias figured by Reif (1973, fig. 8, 1979, fig. 2).
The teeth of these two species differ in certain proportion ratios not directly connected with size differences, but leaving this aside the teeth are roughly similar in shape. A broad similarity in fibrous architecture can therefore be expected in their coronoïn if this, as maintained by Preuschoft et al. (1974), is structurally adapted adding mechanical strength to the teeth making them resistant both to abrasion and to compressional and tensile stresses.

However, this hardly explains the detailed similarity which can be observed in the coronoïn fibrous architecture of the two species: The ratio of the woven-textured layer to the overlying cross-textured layer, the mode of transition between the two coronoin varieties and several other minor features. This correspondance seems too close to be explained by the Preuschoft $e t$ al. theory just referred to. It rather indicates the close phyletic relationship between the two $C$. species.

Even if this is the correct interpretation of the features of these two species, it does not necessarily imply that similar consistencies in fibrous architecture always occur in the coronoiin of other euselachian species which on other grounds are believed to belong to one and the same genus. It is, however, a topic worth keeping in mind during future SEM survey of euselachian coronoïn. If positive indications should be forthcoming then comparative study of tegmental coronoïn fibrous architecture would provide a considerably wider vista for the evaluation of euselachian taxonomy than those indicated by Reif (1977, 1978, 1980).

\section{Comments on nomenclature}

The fact that the traditional genus and species name of Carcharodon megalodon Agassiz has been chosen in this paper instead of Procarcharodon megalodon or Megaselachus megalodon introduced by Casier (1960) and Glikman (1964: 73, 104, 135; 1967: 339; see also Belyaev \& Glikman 1970a, b) respectively, makes it appropriate to clarify the present confusion concerning the nomenclature and taxonomical status of this extinct lamniform and other euselachians which various workers have considered alongside it.

(1) For more than a century general practice has 
been to label detached euselachian teeth yielded by Tertiary deposits and showing a trend in general shape towards that of extant $C$. carcharias teeth as species of that genus. The papers by $\mathrm{Ca}$ sier and Glikman referred to above may be seen as serious attempts to break away from this practice.

Like Casier, Glikman and others the present writer does not believe that mere tooth shape of C. -like teeth suffices for a safe generic classification. A delta-shaped crown with serrated cutting edges is, in fact, characteristic of certain Carboniferous selachian teeth known as Dicrenodus dentatus (see e.g. Romanowsky 1853; Davis 1884) which made up the dentition, possibly of some member of the poorly known cladodont group. Following classic practice these would almost certainly be labelled Carcharodon if their crowns were found in Tertiary deposits.

(2) Several euselachian lineages, which occurred during Tertiary times, probably had a common tendency to develop $C$.-like teeth and dentitions although the phyletic kinships between these lineages were not necessarily particularly close. A similar view was held by Casier (1960) and has received support from the case of Isurus (Oxyrhina) escheri clarified by Bosch (1963: 30- 32).

According to Casier (1960), three genera (Palaeocarcharodon, Procarcharodon and Carcharodon) could be recognized among Tertiary euselachians with $C$.-like dentitions. Casier (1960: 13-16) believed that each of these three genera represented a separate phyletic lineage; the geologically youngest leading to Carchardon s. str. which (so Casier maintained) should have originated during the late Miocene from Isurus (Oxyrhina) hastalis or a closely related form.

Glikman (1964) also claimed that the extant $C$. carcharias had descended phyletically from $I$. (O.) hastalis, but he established the latter species as the type for an entirely new genus: Cosmopolitodus (see also Glikman 1967: 340).

Glikman $(1964,1967)$ also reintroduced the long rejected genus name Otodus to include several species which writers had accepted for decades as pertaining to the genus Carcharodon (e.g. C. auriculatus, C. angustidens, C. angustidens var. turgidus; see e.g. Leriche 1910), but which according to Casier (1960) were species of the genus Procarcharodon. Nomenclature and systematics were further obscured when Glikman
(1964, 1967; see also Belyaev \& Glikman 1970a, b) introduced the new genus name of Megaselachus. The type chosen for this genus was $C$. megalodon which Casier (1960) had renamed Procarcharodon megalodon!

(3) Generally speaking the two Glikman papers just referred to added little in clarifying selachian phylogeny and fossil selachian taxonomy. Some unorthodox views presented by Glikman have already been criticized by e.g. Patterson (1966) and Compagno (1973), but many points still require comment.

Turning first to the genus name of Cosmopolitodus, it is noteworthy that the type Glikman chose (i.e. Oxyrhina hastalis) is now recognized as a species of Isurus (Bosch 1969, 1978, 1980; Bosch et al. 1975). Incidentally, this identification is supported by evidence from dentition pattern and skeleton structure shown by the partially preserved specimen found in late Tertiary deposits of Tuscany and recorded by Lawley $(1876,1877,1881)$ in now rarely cited papers. Thus the name of Cosmopolitodus Glikman is just another synonym for the genus Isurus (see also Romer 1966: 350).

Secondly, the writer cannot find anything which warrants the reintroduction of Otodus (type Otodus obliquus) as a valid generic concept. Neither could Casier (1967: 26). The genus name of Otodus is obsolete and should be relgated entirely to the role of a mere synonym for relevant recognized valid genera (see examples cited below: p. 25) as indeed has long been the practice (cf. eg. Woodward 1889).

Thirdly, the genus names of Palaeocarcharodon and Procarcharodon coined by Casier (1960; noting as types "Carcharodon" landanensis and "Carcharodon" angustidens, respectively) were ill chosen considering the context where he first used them: to distinguish between genera which he claimed were neither close phytelic relatives of each other nor of Carcharodon. Etymologically these genus names convey exactly the opposite impression.

Regardless of this, the names Palaeocarcharodon and Procarcharodon may still be considered usable for practical purposes including, e.g. recognition (see above: p. 2) and recording in biostratigraphical contexts (see e.g. Ward 1980: 14, 17) of species like Pal. landanensis and Proc. auriculatus, $P$. desauris, $P$. debrayi and $P$. stromeri 
which so far are known only from detached teeth and whose phyletic kinships are consequently conjectural.

(4) To make any meaningful evaluation of phyletic affinities and systematic position of any fossil euselachian with $C_{\text {. }}$-like teeth demands, in the writer's opinion, knowledge concerning structural features besides those of the dentition.

This brings us, finally, to the species megalodon and the reasons for maintaining that the proper systematic affiliation of this species lies with the genus Carcharodon, now represented by the single species $C$. carcharias (by some called $C$. rondeleti) which can be traced back into Miocene times (cf. fig. 9).

An apparently almost entire dentition comprising several of the tooth types ( $C$. rectidens, $C$. polygyrus, $C$. subauriculatus), which Leriche (1926) and others (e.g. Menesini 1969) regarded as belonging to the $C$. megalodon dentition, was summarily reported upon by Heckel (1851; cf. Schultz 1971). The specimen, found in deposits at Gairach (Yugoslavia), showed the teeth in association with remains of the jaw calcification. This significant specimen deserves closer attention, description and figuring if it can be redetected in the Vienna collections. So far as the information goes one might suspect that it is the dentition of a perhaps submature $C$. megalodon.

Whatever the above dentition may indicate, the writer is not aware of any finds revealing an undoubted megalodon dentition in definite association with other skeleton remains. There is, however, reason to believe that when such finds turn up the vertebral column will consist of large centra of the kind noted above, with their obvious structural similarity to those of extant $C$. carcharias. By virtue of this similarity, their size, numerical distribution and other features related to their occurrence in e.g. the Belgian Upper Miocene deposits, these centra can hardly be connected with any other selachian than the one whose dentition consisted of the megalodon teeth (Hasse 1879-1885; Leriche 1926: 425-427; Casier 1960: 16). Additional evidence for the close phyletic relationship between the species carcharias and megalodon might be the correspondance in coronoïn fibrous architecture already commented upon (p. 21). Thus the evidence so far available indicates that these two species are congeneric. Accordingly the name Carcharo- don megalodon is the valid one for the extinct species, whereas the names Procarcharodon megalodon (Casier 1960) and Megaselachus megalodon (Glikman 1964, 1967; Belyaev \& Glikman $1970 \mathrm{a}, \mathrm{b})$ are mere additions to the synonym list.

\section{The genus Carcharodon and its species in time and phylogeny}

Three species are referred in this paper to the genus Carcharodon, namely C. turgidus, C. megalodon and $C$. carcharias which, according to structural similarities already touched upon above or to be considered in the sequel, can be regarded as true phyletic relatives.

A broadly identical opinion was long held by many writers, but it was eventually considered untenable by Casier (1960) whose hypothesis regarding the phylogenetic positions of the three species under consideration has already been referred to above (p. 22). Like Keyes (1972), the present writer has felt the Casier hypothesis inadequately supported. For example, the claimed close relationship between Isurus (Oxyrhina) hastalis (or a variant of this species) and $C$. carcharias remains, so it appears, entirely unsupported by any significant similarities shared by the two species (see also Keyes 1972: 239-240), but the view seems nevertheless to have found wide acceptance. Considering the evidence now accumulated in these pages there remains hardly much doubt about the untenability of Casier's hypothesis which, accordingly, is rejected.

The three $C$. species under consideration are all known from deposits in the NW European region. Here, the species $C$. carcharias makes, according to Bosch (pers. comm. 1982; see also Bosch et al. 1975: 105), its first safely dated occurrence just above the Miocene/Pliocene boundary, whereas $C$. megalodon (Bosch pers. comm. 1982) disappears from the fauna well below this stratigraphic boundary. The Gram tooth should, also according to Bosch (pers. comm. 1982), actually represent the latest occurrence within the NW European region of this species from a well-dated non-reworked specimen. Whether $C$. megalodon survived elsewhere into Pliocene times, as generally maintained (see e.g. Leriche 1936, 1938; Schultz 1969, 1971; Mene- 


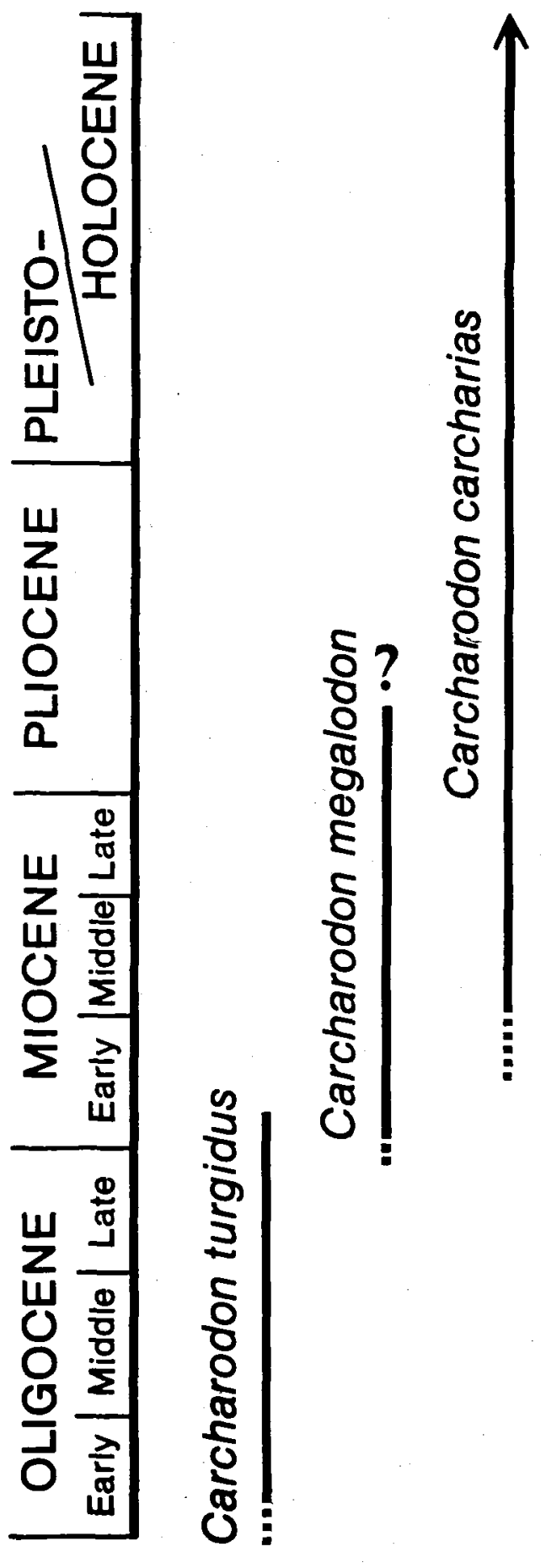

Fig. 9. Known occurrence in time of the three species which, according to their structural features briefly discussed in this paper, are recognized as representatives of the genus Carcharodon. sini 1969; Belyaev \& Glikman 1970b; Keyes 1972), or it became universally extinct in the late Miocene as suggested by Bosch (pers. comm. 1982), remains to be clarified. It is of no consequence in the present context where it is the early occurrence of this species and of $C$. carcharias relative to the latest appearance in time of $C$. turgidus that merit interest.

The extant species $C$. carcharias can be traced back at least into the early Middle Miocene from teeth found in Langian stage deposits (Menesini 1968 ) in both Switzerland (Leriche 1927) and Spain (Bauzá Rullán 1949). These teeth, it may be added, display all features typical for the species and cannot be confused with for example teeth of smaller individuals of contemporary $C$. megalodon. However, the finds are few, so the species shows an infrequent occurrence during the Middle and Upper Miocene in S and MidEurope. Obviously it was not a common element of the native elasmobranch fauna of the seas which then covered this geographical region, but the species could, and did, occassionally migrate into these waters from its true bioprovince even in early Middle Miocene times. Incidentally its occurrence at that time in $\mathbf{S}$ and Mid-Europe is contemporaneous with the northward shift also in this part of the world of a mollusc fauna of a warm water regime (cf. Steininger et al. 1976: 190). Where $C$. carcharias has its centre of migration located at that time cannot be decided yet, but it was probably there that the species evolved and became established somewhat earlier, i.e. during Lower Miocene times.

C. megalodon was, in its early form (given the subspecies name of $C$. megalodon chubutensis by some workers; see however Menesine (1969) with whom the writer agrees), already well established throughout seas covering parts of $\mathrm{W}, \mathrm{S}$ and Mid-Europe and regions elsewhere around the Mediterranean by the early Miocene (Schultz 1968; Menesini 1969; Brzobohatý et al. 1975). Its earliest definitely dated occurrence seems so far to be that in the Austrian Melker series which is chronostratigraphically placed near the top of the Egerian stage (see e.g. Steininger et al. 1976), but the species has been reported from deposits believed to be of Oligocene age (e.g. Erasmo 1922; Keyes 1972).

Definite evidence for the occurrence of the genus $C$. in Oligocene times is provided by two 
partially preserved specimens of yet another species, recovered from the Belgian Rupelian deposits (Dolle 1887; Leriche 1910: 289-293; 1926: 425-427) at Steendorp and Terhagen where the Clay of Boom is exposed in pits (cf. Steurbaut \& Herman 1978).

The identification of these two specimens as representing a species of $C$. is based on dentition features and shape and other characters of the vertebral centra in comparison with corresponding structures in the extant species. But, unlike the $C$. megalodon fossil material, the Rupelian species is known from associated larger parts of the lyodont, polyphyodont dentition and considerable parts of the vertebral column preserved in both specimens. There is, accordingly, good evidence for the determination of the species which, contrary to what Casier (1960) and Glikman $(1964,1967)$ maintained, undoubtedly represent some early but genuine species of $C$. They were in this respect correctly interpreted by Dollo (1887), Woodward (1889), and Leriche (1910, 1926).

Certain minor differences in tooth morphology between the two Rupelian specimens have caused some confusion as to their specific identity. Dollo (1887) recorded both specimens under the species name of heterodon; Woodward (1889) referred both to the species angustidens whereas Leriche $(1910,1926)$ regarded one as belonging to angustidens and the other as a subspecies of it: angustidens var. turgidus. Casier (1960) maintained that they are conspecific, as does the present writer. Casier referred them to the species angustidens; but the present writer tends to believe that Glikman's (1964) evaluation (based entirely on tooth morphology) presents the right conclusion and the Rupelian specimens are thus discussed here under the name of $C$. turgidus.

It is essentially an Oligocene species, but there are finds indicating that a late $C$. turgidus variant (named C.angustidens angustidens by Bzrobohatý \& Schultz 1971) lingered on and is apparently fairly widespread in Lower Miocene deposits from some parts of Europe (France: Leriche 1926: 425; Switzerland: Leriche 1927: 77; Austria: Brzobohatý \& Schultz 1971: 729). If this material, exclusively consisting of detached teeth, is correctly identified, the latest occurrence here of the species seems to be in the Eggenburgian stage deposits of the Central Paratethys. It is, on the other hand, worth mentioning that some among these late occurring teeth could perhaps pertain, as lower jaw teeth, to the dentition of early C. megalodon.

At present it is futile to ponder on which, if any, of the various detached types of $C$.-like teeth among the Lower Tertiary (more precisely preOligocene) fossil material might represent genuine species of that genus. Just where and when the genus emerged phylogenetically cannot be decided either. There is, on the other hand, evidence suggesting that $C$. at the genus level is closely related to Isurus and Lamna since these three genera, according to recent material surveyed by Compagno (1973: 52), “. . . are sufficiently similar in cranial, dentitional and external characters to be placed in one family...". It appears, therefore, reasonable to assume like Casier $(1946,1960)$ that the closest phyletic relatives of the genus under consideration are to be sought among some late Mesozoic or early Tertiary "Lamna" species such as e.g. the Upper Cretaceous " $L$. ." appendiculata (= Cretolamna appendiculata: Glikman 1958, 1964, 1967; Herman 1975 ) or the Eocene "L." obliqua (= Otodus obliquus: Woodward 1899; Glikman 1964, 1967; Blot 1969; Herman 1975). As recorded by Casier (1946), the latter species has vertebral centra whose structural and proportional features are reminiscent of, and could perhaps be ancestral to, those of the $C$. species.

Two of the three $C$. species recognized in this paper $-C$. megalodon and $C$. carcharias - show a world-wide distribution during the Miocene and the Pliocene respectively (Leriche 1936) and the third species - C. turgidus - apparently had a similar occurrence during the Oligocene (cf. Glikman 1964, 1967). C. turgidus seems to have lingered on well into the Lower Miocene, at any rate in the seas then covering southwestern and Mid-Europe (Leriche 1926, 1927; Brzobohatý \& Schultz 1971; Brzobohatý et al. 1975). Here and to the south $C$. megalodon is part of the elasmobranch faunas from at least the beginning of the Miocene (Menesini 1969; Brzobohatý et al. 1975). Within the same geographic area the third species - the still-living C. carcharias - makes its first appearance (according to Leriche 1927, 1936; Bauzá Rullán 1949; Menesini 1968) in deposits now referred to the early Middle Miocene, but the species no doubt evolved elsewhere at a 

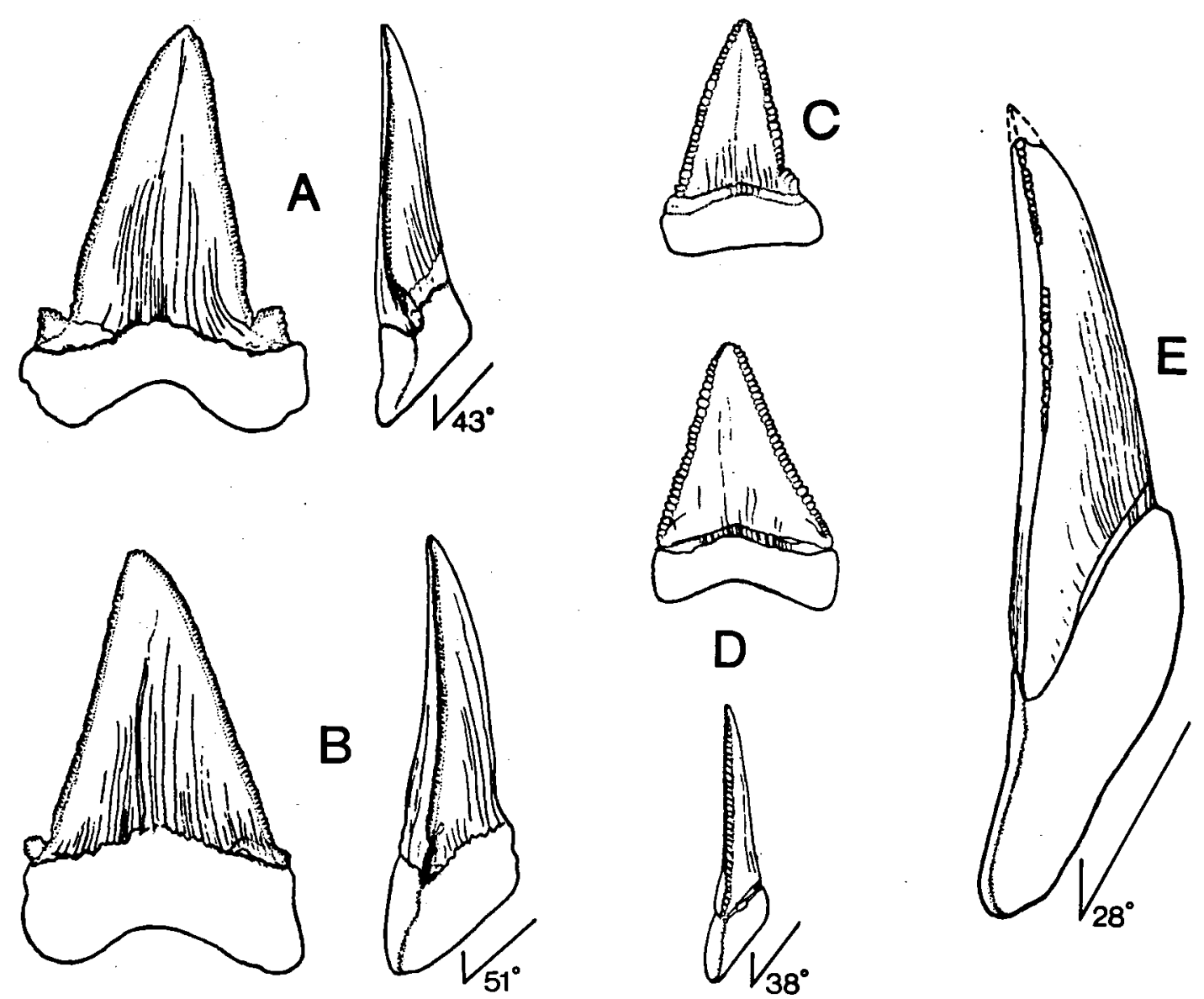

Fig. 10. A-B: Upper jaw teeth from articulated dentitions of two specimens of Carcharodon turgidus (differing slightly in size) from the Rupelian deposits of Belgium; (A) from second right side tooth row of smaller specimen, (B) from same tooth row, but of the left side, of the larger one. C-D: Carcharodon carcharias (recent), upper jaw teeth of (C) young and (D) submature specimen. E: Carcharodon megalodon, Upper Miocene, Gram.

The $C$. turgidus teeth illustrate the tendency in lateral cusp reduction and change in general tooth shape which are correlated with size increase, clearly resembling and probably corresponding to the trends characteristic for teeth of recent $C$. carcharias growing from (C) young to (D) submature age. Size of angle between basal surface and vertical axis indicated.

A-B: Redrawn from Leriche 1910: Pls 17: 2-2a; 18: 1-1a; $x 2 / 3$. C-D: Both figured in $x 1$ from entire dentitions of, respectively, Zool. Mus. (Copenhagen) spec. nr. 1.B. and nr. 1.A. 1.10.1882 (leg Brun, Algier). E: x2/3.

somewhat earlier date, probably well before the end of Lower Miocene times.

This temporal distribution of the three $C$. species tallies with a suggestion that $C$. turgidus could be phyletically ancestral to the two other species. Therefore, the known structural features of the three species will be briefly considered and evaluated.

The similarity in structure of the vertebral centra (and presumably the entire vertebral column) of the three species suggests a derived character common to all species of the genus. Other derived characters of similar status may be the dentition pattern of the upper and lower jaw and differences in tooth shape: the upper jaw teeth have broad delta-shaped crowns while those of the lower jaw having much narrower crowns.

The teeth of $C$. turgidus have relatively bulky crowns compared to those of $C$. megalodon and C. carcharias (fig. 10). One possibly derived character common to the latter two species is the more blade-like tooth crowns; another may be the rather high and steep surface forming the contact of the tooth base with the jaw (fig. 10 
D-E). In C. turgidus the tooth base is thick linguo-labially and the basal surface for support on the jaw generally forms a large angle $\left(43^{\circ}-51^{\circ}\right)$ with the vertical axis of the tooth (fig. $10 \mathrm{~A}-\mathrm{B}$ ).

All the $C$. turgidus teeth have the crown flanked, on both sides, by a well developed lateral cusp (fig. 10 A-B; see also Leriche 1910: Pls 17-18). At a glance this feature may seem to represent a conspicuous difference in shape teeth of the two younger species. Lateral cusps are, however, certainly not lacking in teeth of $C$. megalodon (see Menesini 1969, pls 4-5). Even many large teeth, undoubtedly derived from mature individuals of this species, show semiseparate structures (fig. 2B-D), which obviously correspond to the just more individualized cusps in $C$. turgidus. Similar structures are absent in teeth of submature and mature specimens of recent $C$. carcharias, but such structures are clearly discernible in the teeth of young ones ( $c u$, figs 2E-F, $10 \mathrm{C}$; see also Ellis 1976).

In the dentitions of the two articulated $C$. turgidus specimens, derived from the Rupelian deposits of Belgium (Dollo 1887; Leriche 1910), all teeth display separate, or almost separate, lateral cusps which are triangular in shape and have serrated edges. However, the tooth development is not identical in the two specimens. The lateral cusps are proportionally smaller in the teeth of the larger specimen (fig. $10 \mathrm{~A}-\mathrm{B}$ ), even allowing for the difference in relative tooth size between the two specimens. This particular variation in tooth shape between two individuals of the same species suggests differences in sex or age.

Differing body size between females and males of equal age is common among recent shark species, the females being generally slightly larger (Ellis 1976). However, sexual dimorphism in dentition is rare in recent shark species, unlike extant rays and skates (Bigelow \& Schroeder 1953; Peyer 1968: Pl. 6).

Among extant shark species, on the other hand, tooth shape often differs considerably with age. One example is $C$. carcharias, refered to above, and among many others, mention can be made of Lamna nasus and Heterodontus francisci (Garman 1913).

In these circumstances it seems safe to conclude that the differences shown by the two Rupelian C. turgidus specimens in both body size and shape of the teeth, including the develop- ment of the lateral cusps, are related to an age difference between them whatever their sex may be.

It is interesting to note that this interpretation of $C$. turgidus suggests a similar correlation of age with a tendency towards reduction of the lateral cusps and change in general tooth shape as that seen in extant $C$. carcharias. It is quite likely that this is another derived character also shared by these two $C$. species. Broadly corresponding conditions presumably would be found to prevail in the dentition of $C$. megalodon if better preserved, articulated material was available for study of this species. -

This broad analysis of the occurrence in time of the three species and their known structure therefore supports the assumption that the mainly Oligocene $C$. turgidus was the ancestral species to C. megalodon (as has been held by several earlier writers including Casier (1960) and Glikman (1964, 1967)), and also to C. carcharias. It is, of course, possible to theorize that an unknown species may have given rise both to $C$. turgidus and to the two younger species. However, to fulfil the role as ancestor of the two latter species, this hypothetical species would be expected to show much the same traits and trends in structure as those characteristic of $C$. turgidus. In these circumstances such a hypothesis has little practical interest and, in the writers opinion, thus requires no further consideration here.

Acknowledgements. Mr. J. Knoop (Niebüll-Gotteskoog, BRD-2260) is thanked for the loan of the $C$. megalodon tooth found at Gram. Dr. E. Bertelsen (Zoologisk Museum, Copenhagen) kindly loaned material of extant $C$. carcharias. Conservator S. Bo Andersen (Geologisk Institut, Aarhus) generously provided information on coccoliths found and determined by himself from sediment adhering to the specimen MGUH 1414.

The SEM investigation of enameloid in $C$. megalodon is an extension of similar studies of this hard tissue in dentitions of Palaeo- and Mesozoic elasmobranchs (results of which are included in this paper). These studies were commenced several years ago during extended visits to the Paleozoologiska Sektionen (Naturhistoriska Riksmuseet, Stockholm). The writer is deeply indepted to the leader of that institution, Professor $T$. Ørvig, and its excellent staff for unlimited access to all research facilities.

Grants nos. 511-6802 and 516-10322 from the Danish Natural Science Research Foundation (Statens naturvidenskabelige Forskningsråd) provided an economic basis for the Stockholm research visits.

Financial support from the Carlsberg Foundation (Carlsberg Fondet) made possible project studies of Danish Upper Miocene and other Tertiary fossils and deposits in which context this paper appears. 
Technical assistance from the following staff of the Geologisk Museum and Geologisk Centralinstitut (Copenhagen University) is gratefully acknowledged: conservators B. Bang (preparation, chemical analysis, micro- and macrophotography), $M$. Bukh and S. Skytte (field work, 1978), Mr. C. Rasmussen (drawings, retouch, fig. lay out), Mr. J. F. Nielsen (operation of the SEM) and A. K. Brantsen (typing).

Mr. G. Blom assisted at the SEM in Stockholm. Museumsinspektør F. Roth, Mr. G. Bach and Mr. K. Sørensen, all of Gram, kindly assisted in field work, 1978.

Drs. N. Bonde and M. van den Bosch kindly read the manuscript for criticism and suggestions. Dr. J. Bailey improved the English manuscript and Drs E. Makovicky and A. Demina translated the abstract into Russian.

\section{Dansk sammendrag}

Carcharodon megalodon føjes til Danmarks Øvre Miocæne marine fauna på grundlag af en ukomplet, men meget stor, højre overkæbetand taget som løsfund, 1978, fra typelokaliteten for Gram Formationen: Gram teglværks lergrav (Sønderjylland). Fra samme lokalitet stammer en snes store hvirvelcentra, fundet og udgravet samme år og sandsynligvis hidrørende fra samme høj-art; måske endda samme individ som tanden.

Denne uddøde og strukturelt set endnu ufuldstændigt kendte lamniform-arts optraden i Gram leret samstemmer godt med andre fossile organismers (primært mollusker, dinoflagellater og foraminiferer) indikationer for Gram Formationens biostratigrafiske placering. Gram lerets fossile elasmobranch selskab, såvidt det kendes nu, er iøvrigt ikke væsentlig forskelligt fra, men måske lidt fattigere end, dem, rapporteret fra bl.a. Hollands og Belgiens Øvre Miocæn.

Slægten $C$. optræder i Danmark også med arten $C$. turgidus fra disloceret Oligocæn i Ø.-Jylland. Desuden forekommer de C. -lignende tandtyper, der kaldes Procarcharodon auriculatus (N.-M. Eocæn ved Trelde Næs, Ø.-Jylland) og Procarcharodon landanensis (Paleocæn Craniakalk, København), men reprasenterer former, som strukturelt set er helt ukendte, og hvis egentlige slagtskabsforhold derfor er uafklarede.

Analyse af coccolither i sediment fra den $C$. rondeleti tand, som Davis (1890) beskrev som værende fra Faxa, bekræeftede Ravns (i Milthers 1908) skepsis. Tanden er ikke fra Faxe; måske ikke engang fra Danmark. Den stammer fra lag ikke ældre end Eocan, men måske meget yngre.

C. megalodon tanden fra Gram er $\mathrm{i}$ histologisk og ultrastrukturel henseende sxrdeles godt bevaret. Det rigt forgrenede kanalsystem for fine blodkar i tandens base er perfekt udfyldt af pyrit; dele af det har kunnet frilægges og afbildes. Kronen består af osteodentin, dækket, som tænder af euselachier $i$ almindelighed, af et lag enameloid (emaljelignende hård-væv), hvis ultrastrukturelle arkitektur undersøgtes i scanning elektron mikroskop. Resultaterne prasenteres $i$ en bredere komparativ kontekst sammen med delresultater af forfatterens ikke tidligere publicerede SEM og lysmikroskopiske undersøgelser af enameloid fra en række Palæo- og Mesozoiske durofage elasmobranchers tandbevabninger.

Den nye term coronoin introduceres for elasmobranch tand enameloid, og der skelnes mellem tegmental coronoïn (som hos bl.a. C. megalodon) og vascular coronoin (hos Palæozoiske bradyodonter og visse Mesozoiske durofage selachier). Ligeledes prasenteres en forbedret klassifikation af coronoin ultrastrukturer, der, som hos andre mesodermalt deriverede, hypermineraliserede hård-vav (acrodin og ganoin hos actinopterygier; pleromin varianter hos bl.a. dipnoi og chimaeroider), afspejler den oprindelige anordning af kollagen fibriller tilstede $i$ den organiske matrix (i narvarende tilfalde pracoronoin) ud af hvilken den pågxldende enameloid formeres ontogenetisk, som kendt fra recent materiale, gennem komplekse histogenetiske processer, sluttelig førende til hypermineralisation.

Skønt coronoin og acrodin viser en del lighed, kan disse to enameloider klart adskilles strukturelt. Og det er muligt, at disse strukturelle forskelligheder afspejler distinkte, men endnu ikke kendte forskelle også med hensyn til visse processer under de to enameloiders respektive ontogenetiske dannelse. Noget sådan ville ikke være overraskende, når man tager $i$ betragtning, at elasmobrancher (med coronoïn) og actinopterygier (med acrodin) fylogenetisk skildtes langt tilbage i Palæozoikum.

Hvad angár coronoïn og pleromin hos f.eks. chimaeroider er de basalt forskellige bl.a. med hensyn til så vigtige træk som: (1) deres respektive histologisk topografiske relationer til andre hård-væv i de pågxldende dentitioner; og (2) deres respektive ontogeni og histogenese. Faktisk er disse forskelle så betydelige, at de må betragtes som tilstrækkelige til at udelukke muligheden for, at chimaeroiderne (med deres statodonte dentition) kan være fylogenetiske efterkommere af nogen kendt bradyodontid gruppe eller, for den sags skyld, af nogen anden elasmobranch gruppe med tilsvarende lyodontid dentition, inklusive de ejendommelige iniopterygier.

Med hensyn til $C$. megalodon udredes den ret komplicerede situation omkring denne arts (og visse andre euselachiers) nomenklatur, og det klassiske navn rehabiliteres. Alternative navne som Procarcharodon megalodon og Megaselachus megalodon regnes herefter for junior-synonymer.

Det konkluderes slutteligt, at den hovedsageligt Oligocane art $C$. turgidus, alt taget i betragtning, med rimelighed kan antages at være den fylogenetiske forløber både for den uddøde $C$. megalodon og for den stadig eksisterende art $C$. carcharias.

\section{References}

Agassiz, L. 1836: Recherches sur les Poissons fossiles. 2: $8+$ $390+34$ pp., Atlas 83 pls.

Bauzá Rullán, J. 1949: Nuevas contribuciones a la fauna ictiológica fósil del Neógeno de España. Boln. R. Soc. esp. Hist nat. (vol. straordinario): 471-504.

Belyaev, G. M. \& Glikman, L. S. 1970a: The teeth of sharks on the floor of the Pacific Ocean. Trudy Inst. Okeanol. Akad. Nauk SSSR 88: 252-276. (In Russian with English summary).

Belyaev, G. M. \& Glikman, L. S. 1970b: On the geological age of the teeth of shark Megaselachus megalodon (Ag.). Trudȳ Inst. Okeanol. Akad. Nauk SSSR 88: 277-280. (In Russian with English summary).

Bendix-Almgreen, S. E. 1968: The bradyodont elasmobranchs and their affinities; a discussion. In: Ørvig, T. (Ed.): Current problems of lower vertebrate phylogeny. Nobel Symp. 4: 153-170. Almquist \& Wiksell, Stockholm.

Bendix-Almgreen, S. E. 1971: The anatomy of Menaspis armata and the phyletic affinities of the menaspid bradyodonts. Lethaia 4: 21-49.

Bendix-Almgreen, S. E. 1975: Fossil fishes from the marine late Palaeozoic of Holm Land-Amdrup Land, North-East Greenland. Meddr Gronland 195 (9): 1-38.

Bendix-Almgreen, S. E. 1982a: Description and stratigraphical evaluation of some late Palaeozoic fishes from Nan Shan (western China), with a discussion of bradyodont dentitions and their phyletic significance in comparison with those of elasmobranchiomorphs in general. (Manuscript)

Bendix-Almgreen, S. E. 1982b: Stor, større, - Carcharodon megalodon, - en ganske sarlig hajtand fra Gram-leret. Nordslesvigske Museer 9: 15-37. (In Danish with English summary) 
Bendix-Almgreen, S. E. \& Roth, F. 1976: Fortidshvalen fra Sønderjyllands undergrund. In: Carlsbergfondets, Frederiksborgmuseets og $\mathrm{Ny}$ Carlsbergfondets beretning for aret 1974-1975: 34-38. Rhodos, København. (In Danish).

Bigelow, H. B. \& Schroeder, W. C. 1953: Fishes of the western North Atlantic. Sawfishes, guitarfishes, skates, rays and chimaeroids. Mem. Sears. Fdn. Mar. Res. 1 (2 vols): $1-588$.

Blot, J. 1969: Holocéphales et Elasmobranches: Systématique. In: Piveteau, J. (Ed.): Traité de Paléontologie 4(2): 702-776.

Bosch, M. van den 1964: De Haaientanden uit de transgressielagen in de Scharberg bij Elsloo. Natuurh. Maandbl. 53: 19-25.

Bosch, M. van den 1969: Het Mioceen van Delden. III: De Selachierrauna uit de miocene afzettingen in het Twentekanal bij Delden. Publ. Natuurh. Genootsch. Limburg 19: 25-36.

Bosch, M. van den 1978: On shark teeth and scales from the Netherlands and the biostratigraphy of the Tertiary of the eastern part of the country. Meded. Werkgr. Tert. Kwart. Geol. 15: 129-136.

Bosch, M. van den 1980: Elasmobranch associations in Tertiary and Quaternary deposits of the Netherlands (Vertebrate, Pisces), 2. Paleogene of the eastern and northern part of the Netherlands, Neogene in the eastern part of the Netherlands. Meded. Werkgr. Tert. Kwart. Geol. 17: 65-70.

Bosch, M. van den, Cadée, M. C. \& Janssen, A. W. 1975: Lithostratigraphical and biostratigraphical subdivision of Tertiary deposits (Oligocene-Pliocene) in the WinterswijkAlmelo region (eastern part of the Netherlands). Scripta Geol. 29: 1-169.

Brzobohatý, R. \& Schultz, O. 1971: Die Fischfauna der Eggenburger Schichtengruppe. In: Steininger, F. \& Senes, J. (Eds): $M_{1}-$ Eggenburgien. - Chronostrat. \& Neostrat. 2: 719-759.

Brzobohatý, R., Kalabis, V. \& Schultz, O. 1975: Die Fischfauna des Egerien. In: Baldi, T. \& Senes, J. (Eds.): $O M-$ Egerien. - Chronostrat. \& Neostrat. 5: 457-477.

Casier, E. 1946: La Faune ichthyologique de l'Yprésien de la Belgique. Mém. mus. r. Hist. nat. Belg. 104: 1-267.

Casier, E. 1960: Note sur la collection des poissons Paléocènes et Eocènes de l'Enclave de Cabinda (Congo). Annls Mus. r. Congo belge (3), 1(2): 1-47.

Casier, E. 1967: Le Landénien de Dormaal (Brabant) et sa faune ichthyologique. Mém. inst. r. Sci. nat. Belg. 156: $1-66$.

Ceuster, J. de 1976: Stratigrafische interpretatie van jongcenozoische afzettingen bij Rumst (Belgie, provincie Antwerpen) en beschrijving van de in een post-mioceen basisgrind aangetroffen vissenfauna. 1. Inleiding en stratigrafische gegevens. II. Systematische beschrijvingen en conclusies. Meded. Werkgr. Tert. Kwart. Geol. 13: 119- 172.

Compagno, L. J. V. 1973: Interrelationships of living elasmobranchs. In: Greenwood, P. H., Miles, R. S. \& Patterson, C. (Eds.): Interrelationships of fishes, 15-61. Linn. Soc. Lond. Academic Press. London.

Daculsi, G. \& Kerebel, L. M. 1980: Ultrastructural study and comparative analysis of fluoride content of enameloid in sea-water and fresh-water sharks. Archs oral Biol. 25: 145-151.

Davis, J. W. 1883: On the fossil fishes of the Carboniferous limestone of Great Britain. Scient. Trans. R. Dubl. Soc. (2), 1: 327-600.

Davis, J. W. 1890: On the fossil fish of the Cretaceous formations of Scandinavia. Scient. Trans. R. Dubl. Soc. (2), 4: $363-434$
Dollo, L. 1887: Le Hainosaure et les nouveaux vertébrés fossiles du Musée de Bruxelles. Rev. Quest. scient. 22: 70112.

Dollo, L. 1907: Les ptyctodontes sont des arthrodères. Bull. Soc. belge Geol. Paléont. Hydrol. 21: 1-12.

Ellis, R. 1976: The book of sharks. 320 pp. Grosset \& Dunlap, New York

Erasmo, G. d' 1922: Catalogo dei pesci fossili delle Tre Venezie. Mem. Ist. geol. Mineral. Univ. Padova 6: $181 \mathrm{pp.}$

Friis, H., Nielsen, O. B. \& Heilmann-Clausen, C. 1981: Guide to excursion 14th May, 1981. I. G. C. P. Project 124. The NW European Tertiary Basin: 1-71.

Garant, P. R. 1970: An electron microscopic study of the crystal-matrix relationship in the teeth of the dogfish Squalus acanthias L. J. Ultrastruct: Res: 30: 441-449.

Garman, S. 1913: The plagiostomia (Sharks, skates and rays). Mem. Mus. comp. Zool. Harv. 36: 1-528.

Geamers, P. A. M. 1978: A biozonation based on gadidae otoliths for the northwest European younger Cenozoic, with the description of some new species and genera. Meded. Werkgr. Tert. Kwart. Geol. 15: 141-161.

Geyn, W. A. E. van de 1937: Das Tertiär der Niederlande mit besonderer Berücksichtigung der Selachierfauna. $190 \mathrm{pp}$. Leiden.

Glikman, L. S. 1958: O tempakh evolyutsii lamnoidnykh akul (Rates of evolution in lamnoid sharks.). Doklady Akad. Nauk. SSSR 123(3): 568-672.

Glikman, L. S. 1964: Akuly paleogena $i$ ikh stratigraficheskoe znachenie. 229 pp. Akad. Nauk SSSR. Moscow. [In Russian].

Glikman, L. S. 1967: Subclass Elasmobranchii (sharks). In: Orlov, Y. A. (Ed.): Fundamentals of Paleontology 11: 292-352. Israel Progr. Sci. Transl. Jerusalem.

Goto, M. 1976: Development of shark teeth and phylogeny of teeth in vertebrates. Earth Sci. 30: 206-221.

Goto, M. 1978a: [Histological and biochemical studies on recent and fossil shark teeth]. Tsurumi Univ., dent. J. 4: 85-104. [In Japanese with English summary].

Goto, M. 1978b: [Histogenetic studies on the teeth of the leopard shark (Triakis scyllia)]. J. stomat. Soc. Japan 45: 527-584. [In Japanese].

Gross, W. 1968: Fraglische Actinopterygier-Schuppen aus dem Silur Gotlands. Lethaia 1: 184-218.

Gross, W. 1969: Lophosteus superbus Pander, ein Teleostome aus dem Silur Oesels. Lethaia 2: 15-47.

Gross, W. 1971: Lophosteus superbus Pander: Zähne, Zahnknochen und besondere Schuppenformen. Lethaia 4: 131152.

Gross, W. 1973: Kleinschuppen, Flossenstacheln und Zähne von Fischen aus europäischen und nordamerikanischen Bonebeds des Devons. Palaeontographica (A) 142: 51155.

Hasse, J. C. F. 1879-1885: Das natürliche System der Elasmobranchier auf Grundlage des Baues und der Entwicklung ihrer Wirbelsäule. $385+27$ pp. Gustav Fischer, Jena.

Heckel, J. 1851: Gebiss eines fossilen Haies von Gairach in Unter-Steiermark. Jb. geol. Bundesanst. Wien 2: 149.

Herman, J. 1975: Les Sélaciens des terrains néocrétacés et paléocènes de Belgique et des contrées limitrophes; éléments d'une biostratigraphie intercontinentale. Mém. Expl. Cartes. geol. min. Belg. 15: 1-401.

Herold, R. C. B. 1974: Ultrastructure of odontogenesis in the pike (Esox lucius). Role of dental epithelium and formation of enameloid layer. J. Ultrastruct. Res. 48: 435-454.

Hoch, E. 1975: Amniote remnants from the eastern part of the Lower Eocene North Sea basin. Coll. int. Cent. natn. Rech. scient. 218: 543-562. 
Jaekel, O. 1901: Ueber jurassische Zähne und Eier von Chimäriden. Neues Jb. Miner. Geol. Paläont. 14: 540-564.

Janvier, P. 1971: Nouveau matériel d'Andreolepis hedei Gross, actinoptérygien énigmatique du Silurien de Gotland (Suède). C.r. hebd. Acad. Sci. 273: 2223-2224.

Janvier, P. 1978. On the oldest known teleostome fish Andreolepis hedei Gross (Ludlow of Gotland), and the systematic position of the lophosteids. Eesti NSV Tead. Akad. Toim.: 88-95.

Kemp, N. E. \& Park, J. H. 1974: Ultrastructure of the enamel layer in developing teeth of the shark Carcharinus menisorrah. Archs oral Biol. 19: 633-644.

Kerebel, B. \& Daculsi, G. 1975: Ultrastructure de l'émailoïde des dents de Prionace glauca L. J. Biol. Buccale 3: 3-12.

Kerebel, B., Daculsi, G. \& Renaudin, S. 1977: Ultrastructure des améloblastes au cours de la formation de l'émailoìde des sélaciens. Biol. Cellulaire 28: 125-130.

Kerr, T. 1955: Development and structure of the teeth in the dog fish, Squalus acanthias L. and Scyliorhinus caniculus (L). Proc. zool. Soc. Lond. 125: 95-114.

Kerr, T. 1960: Development and structure of some actinopterygian and urodele teeth. Proc. zool. Soc. Lond. 133: 401-422.

Keyes, J. W. 1972: New records of the elasmobranch $C$. megalodon (Agassiz) and a review of the genus Carcharodon in the New Zealand fossil record. N.Z. Jl. Geol. Geophys. 15: 228-242.

Kjellström, B. 1971: Histological and chemical studies in hard tissues of fossil and recent selachians and in heterostracans. Diss., Dept. of Palaeontology, Univ. of Lund.

Klapper, G., Sandberg, C. A., Collinson, C., Huddle, J. W., Orr, R. W., Rickard, L. V., Schumacher, D., Seddon, G. \& Oyeneo, T. T. 1971: North American Devonian conodont biostratigraphy. In: Sweet, W. C. \& Bergstrom, S. M. (Eds.): Symposium on conodont biostratigraphy. Mem. geol. Soc. Am. 127: 285-316.

Kristoffersen, F. N. 1972: Foraminiferzoneringen i det jyske Miocæn. Dansk geol. Foren., Arsskrift for 1971: 79-85. (In Danish)

Kristoffersen, F. N. 1973: Studies on some Elphidiidae (foraminifera) from the Miocene of Denmark. Danm. geol. Unders., Arbog 1972: 25-36.

Kruchow, T. 1959: Eine untermiocäne Haifisch-Fauna in Schleswig-Holstein. Meyniana 8: 82-95.

Kruchow, T. 1960: Obermiocäne Selachier von HamburgLangenfelde (Langenfelder Stufe). Verh. Ver. naturw. Heimatforsch. Hamburg 34: 55-61.

Kruchow, T. 1961: Miocäne Selachier-Faunen in nordwestdeutschen Randgebieten der Nordsee. Meyniana 10: $42-48$.

Kruchow, T. 1964: Haifisch-Zähne und Fisch-Reste in TertiärGeschieben. Aufschluss 14 (Sonderheft): 57-63.

Kruchow, T. 1965: Die Elasmobranchier des tertiären Nordseebeckens in nordwestdeutschen Bereich. Senckenberg. leth. 46a (Weiler Festschr.): 215-256.

Kvam, T. 1946: Comparative study of the ontogenetic and phylogenetic development of dental enamel. Norske Tannlaegeforen. Tid. 56 suppl.: 1-198.

Kvam, T. 1950: The development of mesodermal enamel of piscine teeth. K. norske Vidensk. Selsk. Forh. 23: 7-115.

Lawley, R. 1876: Nuovi Studi sopra ai Pesci ed altri Vertebrati fossili delle Colline toscane. $122 \mathrm{pp}$.

Lawley, R. 1877: Monografia dei resti del genere Notidanus etc. Atti Soc. Toscana Sci Nat. Mem. 3: 57-76.

Lawley, R. 1881: Studi comparativi sui pesci fossili coi viventi dei generi Carcharodon, Oxyrhina e Galeocerdo. 151 pp. Pisa.

Leriche, M. 1910: Les poissons Oligocènes de la Belgique. Mém. Mus. r. Hist. nat. Belg. 5: 230-363.
Leriche, M. 1920a: L'âge du gravier fossilifère d'EIsloo (Limbourg hollandais), d'après sa faune ichthylologique. - La position du Boldérien dans le Néogène de la Belgique. Bull. Soc. belge Geol. Paléont. Hydrol. 30: 101-115.

Leriche, M. 1920b: Sur les restes de poissons remaniés dans le Néogène de la Belgique. - Leur signification au point de vue de l'histoire géologique de la Belgique pendant le Tertiaire supérieur. Bull. Soc. belge Geol. Paléont. Hydrol. 30: 115-120.

Leriche, M. 1926: Les poissons Néogènes de la Belgique. Mém. Mus. r. Hist. nat. Belg. 32: 365-472.

Leriche, M. 1927: Les poissons de la Molasse Suisse. Mém Soc. Paléont. Suisse 46: 1-55, 47: 47-119.

Leriche, M. 1936: Sur l'importance des Squales fossiles dans l'établissement des synchronismes de formations à grandes distances, et sur la répartition stratigraphique et géographique de quelques espèces tertiaires. Mém. Mus. r. Hist. nat. Belg. 2(3) (Mélanges Paul Pelseneer): 739-773.

Leriche, M. 1938: Contribution à l'étude des Poissons fossiles des pays riverains de la Méditerranée américaine (Venezuela, Trinité, Antilles, Mexique). Mém. Soc. Paléont. Suisse. 59: 1-42.

Leriche, M. 1951: Les poisson Tertiaires de la Belgique (Supplément). Mém. Inst. r. Sci. nat. Belg. 118: 473-600.

Lund, R. 1977a: New information on the evolution of the bradyodont chondrichthyes. Fieldiana, Geol. 33: 521-539.

Lund, R. 1977b: Echinochimaera meltoni, new genus and species (Chimaeriformes) from the Mississippian of Montana. Ann. Carneg. Mus. 46: 195-221.

Mark-Kurik, E. 1975: A tooth-plate from the Lower Devonian of Kotelny Island. Esti NSV Tead. Akad. Toim. Keemia Geologia 4: 307-309.

Menesini, E. 1968: Cirripedi, Echinidi, Elasmobranchi e Pesci (S.S.) del Pliocene de Punta Ristola (Capo di Leuca-Puglia). Mem. Soc. tosc. Sci. nat., Ser. A. 75: 579-596.

Menesini, E. 1969: Ittiodontoliti miocenici di Terra d'Otranto (Puglia). Palaeontogr. ital., n.s. 65: 1-61.

Miles, R. S. \& Young, G. C. 1977: Placoderm interrelationships reconsidered in the light of new ptyctodontids from Gogo, western Australia. In: Andrews, S. M., Miles, R. S. \& Walker, A. D. (Eds.): Problems in vertebrate evolution. Linn. Soc. Symp. Ser. 4: 124-198. Academic Press. London.

Milthers, V. 1908: Beskrivelse til geologisk kort over Danmark (i maalestok 1:100.000). Kortbladene Faxe og Stevns Klint. Danm. geol. Unders. (1) 11: 1-291. (In Danish)

Milthers, V., Milthers K., Rasmussen, L. B., Andersen, S. T. Jakobsen, B., Christensen, H. V. \& Østergaard, K. H. 1957: Ekskursion til Sydvestjylland 7.-9. august 1956. Meddr Dansk geol. Foren. 13: 259-262. (In Danish)

Moskalenko, T. A. 1970: Konodontii krivoluskogo jarus (Srednii Ordovik) Sibirskoi Platformii. Trudy Inst. Geol. Geofiz, sib. Otd. Akad. Nauk SSSR 61: 1-116. (In Russian)

Moss, M. 1977: Skeletal tissues in sharks. Amer. Zool. 17: 335-342.

Moy-Thomas, J. A. 1935: The structure and affinities of Chondrenchelys problematica. Proc. zool. Soc. Lond. 1935(2): 391-403.

Moy-Thomas, J. A. 1936a: On the structure and affinities of the Carboniferous cochliodont Helodus simplex. Geol. Mag. 73: 488-501.

Moy-Thomas, J. A. 1936b: The structure and affinities of the fossil elasmobranch fishes from the Lower Carboniferous rocks of Glencartholm, Eskdale. Proc. zool. Soc. Lond. 1936(3): 761-788.

Moy-Thomas, J. A. 1939a: The early evolution and relationships of the elasmobranchs. Biol. Rev. 14: 1-26.

Moy-Thomas, J. A. 1939b: Palaeozoic fishes. 149 pp. Methuens monograph on biological subjects. Methuen, London. 
Moy-Thomas, J. A. \& Miles, R. S. 1971: Palaeozoic fishes. 259 pp. 2nd ed. Chapman \& Hall. London.

Nielsen, E. 1932: Permo-Carboniferous fishes from East Greenland. Meddr Gronland 86: 1-63.

Nielsen, E. 1952: On new or little known Edestidae from the Permian and Triassic of East Greenland. Meddr Gronland 144: 1-55.

Obruchev, D. V. 1967: Subclass Holocephali (Chimaeras). In: Orlov, Y. A. (Ed.): Fundamentals of Paleontology 11: 292-352. Israel Progr. Sci. Transl. Jerusalem.

Owen, R. 1840-45: Odontography etc.: $74+655$ pp. H. Bailliere, London.

Patterson, C. 1965: The phylogeny of the chimaeroids. Phil. Trans. R. Soc. (B) 249:101-219.

Patterson, C. 1966: British Wealden sharks. Bull. Br. Mus. nat. Hist. A. Geol. 11: 283-350.

Patterson, C. 1968: Menaspis and the bradyodonts. In: Ørvig, $\mathrm{T}$. (Ed.): Current problems of lower vertebrate phylogeny. Nobel Symp. 4: 171-205. Almquist \& Wiksell, Stockholm.

Peyer, B. 1968: Comparative odontology. Zangerl, R. (Ed.). 14 +347 pp. Univ. of Chicago Press.

Piasecki, S. 1980: Dinoflagellate cyst stratigraphy of the Miocene Hodde and Gram formations, Denmark. Bull. geol. Soc. Denmark 29: 53-76.

Poole, D. F. G. 1956: The fine structure of the scales and teeth of Raja clavata. Q. Jl microsc. Sci. 97: 99-107.

Poole, D. F. G. 1967: Phylogeny of tooth tissues: enameloid and enamel in recent vertebrates, with a note on the history of cementum. In: Miles, E. W. (Ed.): Structural and chemical organization of teeth 1: 111-149. Academic Press, New York \& London.

Poole, D. F. G. 1971: An introduction to the phylogeny of calcified tissues. In: Dahlberg, A. A. (Ed.): Dental morphology and evolution: 65-79. Univ. of Chicago Press.

Preuschoft, H., Reif, W.-E. \& Müller, W. H. 1974: Funktionsanpassungen in Form und Struktur an Haifischzähnen. $Z$. Anat. EntwGesch. 143: 315-344.

Radinsky, L. 1961: Tooth histology as a taxonomic criterion for cartilaginous fishes. J. Morph. 109: 73-81.

Rasmussen, L. B, 1954: Fossilførende marint Øvre-Miocæn ved Holleskov nordøst for Ribe. Meddr dansk geol. Foren. 12: 531-540. (In Danish)

Rasmussen, L. B. 1956: The marine Upper Miocene of South Jutland and its molluscan fauna. Danm. geol. Unders. (2) 81: 1-166.

Rasmussen, L. B. 1958: Det marine ungtertiær ved Sæd. Meddr dansk geol. Foren. 14: 1-28. (In Danish)

Rasmussen, L. B. 1959: Vorläufige Bericht über des Miozän von Maade bei Esbjerg. Meddr dansk geol. Foren. 14: 115-121.

Rasmussen, L. B. 1961a: Mittel- und Ober-Miozằn von Dänemark. Meyniana 10: 59-62.

Rasmussen, L. B. 1961b: De Miocæne formationer i Danmark. Danm. geol. Unders. (4), 4(5): 1-45. (In Danish)

Rasmussen, L. B. 1963: Fiskerester, bryozoer og diverse andre organismer fra det yngre miocæn i Danmark. Meddr dansk geol. Foren. 15: 272. (In Danish)

Rasmussen, L. B. 1966: Biostratigraphical studies on the marine younger Miocene of Denmark; based on the molluscan faunas. Danm. geol. Unders. (2) 88: 1-358.

Rasmussen, L. B. 1968: Molluscan faunas and biostratigraphy of the marine younger Miocene formations in Denmark. Danm. geol. Unders. (2) 92: 1-265.

Ravn, J. P. J. 1907: Molluskfaunaen i Jyllands Tertiæraflejringer. [Résumé en français]. Kgl. Danske Vidensk. Selsk. Skr. 7. Rk. Afd. 3, 2: 215-386.

Regan, T. 1910: The origin of the chimaeroid fishes. Int. Congr. Zool. 7. Boston, 1907: 1-2.
Reif, W.-E. 1973: Morphologie und Ultrastruktur des Hai»Schmelzes «. Zool. Scr. 2: 231-250.

Reif, W.-E. 1977: Tooth enameloid as a taxonomic criterion: 1 . A new euselachian shark from the Rhaetic-Liassic boundary. Neues Jb. Geol. Paläont. Mh. 1977(9): 565-576.

Reif, W.-E. 1978: Tooth enameloid as a taxonomic criterion: 2. Is "Dalatias" barnstonensis SYKES, 1971 (Triassic, England) a squalomorphic shark? Neues $\mathrm{Jb}$. Geol. Paläont. Mh. 1978(1): 42-58.

Reif, W.-E. 1979: Structural convergences between enameloid of actinopterygian teeth and of shark teeth. Scanning Electron Microsc. 2: 546-554.

Reif, W.-E. 1980a: Tooth enameloid as a taxonomic criterion: 3. A new primitive shark family from the Lower Keuper. Neues Jb. Geol. Paläont. Abh. 1: 61-72.

Reif, W.-E. 1980b: Development of dentition and dermal skeleton in embryonic Scyliorhinus canicula. J. Morph. 166: 275-288.

Richter, A. E. 1978: Walwirbel, Krabben und Schnecken, Miozänfossilien aus Dänemark. Mineralien Mag. 2: 221-228.

Ripa, L. W., Gwinnett, A. J., Guzman, C. \& Legler, D. 1972: Microstructural and microradiographic qualities of lemon shark enameloid. Archs oral Biol. 17: 165-173.

Romanowsky, H. 1853: Ueber eine neue Gattung versteinerter Fisch-Zähne. Bull. Soc. (imp.) Nat. Moscou 26(1): 405-409.

Romer, A. 1966: Vertebrate Paleontology, 3rd edr. 1-468. University Press. Chicago.

Rosenkrantz, A. 1920: Craniakalk fra Kjøbenhavns Sydhavn. Danm. geol. Unders. (2) 36: 1-79. (In Dansih)

Roth, F. 1978: Mesocetus argillarius sp. n. (Cetacea, Mysticeti) from Upper Miocene of Denmark, with remarks on the lower jaw and the echolocation system in whale phylogeny. Zool. Scr. 7: 63-79.

Roth, F. 1980: Portrat af en afdød - Comments on a baleen whale skeleton from the Gram Formation (Upper Miocene) of Denmark. Nordslesvigske Museer 7: 13-26 + 153-155.

Schmidt, W. J. 1958: Faserung und Durodentin-Metaplasie bei Fischzähnen. Anat. Anz. 105: 349-360.

Schmidt, W. J. \& Keil, A. 1958: Die gesunden und die erkranken Zahngewebe des Menschen und der Wirbeltiere im Polarisationsmikroskop. 386 pp. Carl Hanser, München.

Schultz, O. 1969: Die Selachierfauna (Pisces, Elasmobranchii) aus den Phosphoritensanden (Unter Miozän) von Plesching bei Linz, Oberösterreich. - (Mit einem Beitrag von Friederich Steininger). Naturh. Jb. Stadt Linz 14 (1968): 60-102.

Schultz, O. 1971: Die Selachier-Fauna (Pisces, Elasmobranchii) des Wiener Beckens und seiner Randgebiete im Badenien (Miozän). Annln naturh. Mus. Wien 75: 311341.

Shaeffer, B. \& Williams, M. 1977: Relationships of fossil and living elasmobranchs, Am. Zool. 17: 293-302.

Shellis, R. P. 1975: A histological and histochemical study of the matrices of enameloid and dentine in teleost fishes. Archs oral Biol. 20: 183-187.

Shellis, R. P. \& Berkovitz, B. K. B. 1976: Observations on the dental anatomy of piranhas (Characidae) with special reference to tooth structure. J. Zool. Lond. 180:69-84.

Shellis, R. P. \& Miles, A. E. W. 1974: Autoradiographic study of the formation of enameloid and dentine matrices in teleost fishes using tritiated amino acids. Proc. $R$. Soc. Lond. B. 185: 51-72.

Shellis, R. P. \& Miles, A. E. W. 1976: Observations with the electron microscope on enameloid formation in the common eel (Anguilla anguilla; Teleostei). Proc. R. Soc. Lond., B. 194: 253-269. 
Smith, M. M. 1977: The microstructure of the dentition and dermal ornament of three dipnoans from the Devonian of Western Australia: a contribution towards dipnoan interrelations, and morphogenesis, growth and adaptation of the skeletal tissues. Phil. Trans. R. Soc. (B) 281: 29-72.

Smith, M. M. 1979: Structure and histogenesis of the tooth plates in Sagenodus inaequalis Owen considered in relation to the phylogeny of post-Devonian dipnoans. Proc. $R$. Soc. Lond. (B) 204: 15-39.

Sorgenfrei, T. 1940: Marint Nedre-Miocæen i Klintingehoved p̊̊ Als. Et bidrag til Løsning af Aquitanien-Spørgsmálet. Danm. geol. Unders. (2) 65: 1-143. (In Danish)

Sorgenfrei, T. 1958: Molluscan assemblages from the marine middle Miocene of South Jutland and their environments. Danm. geol. Unders. (2) 79: 1-503.

Sorgenfrei, T. 1961: Die Entwicklung des unteren und mittleren Miozän in südlichen Dänemark. Meyniana 10: 53-58.

Stahl, B. J. 1974: Vertebrate history: Problems in evolution. $9+$ 594 pp. McGraw-Hill, New York.

Stahl, B. J. 1980: Non-autostylic Pennsylvanian iniopterygian fishes. Palaeontology 23: 315-324.

Steininger, F., Rögel, F. \& Martini, E. 1976: Current Oligocene/Miocene biostratigraphic concept of the Central Paratethys. Newsl. Stratigr. 4: 174-202.

Steurbaut, E. \& Herman, J. 1978: Biostratigraphie et poissons fossiles de la formation de l'argile de Boom (Oligocène moyen de Bassin Belge). Geobios 11: 297-325.

Thorsteinsson, R. 1973: Dermal elements of a new lower vertebrate from Middle Silurian (Upper Wenlockian) rocks of the Canadian Arctic Archipelago. In: Schultze, H.-P. (Ed.): Festband W. Gross. Palaeontographica (A) 143: 51-57.

Ward, D. J. 1980: The distribution of sharks, rays and chimaeroids in the English Palaeogene. Tert. Res. 3: 13- 19.

Weiler, W. 1961: Bericht über die Fischfauna der mittelmiocänen Nordsee. Meyniana 10: 49-52.

Woodward, A. S. 1889: Catalogue of the fossil fishes in the British Museum (Natural History). I. Elasmobranchii. $\mathrm{Br}$. Mus. (Nat. Hist.): $47+474$ pp.

Woodward, A. S. 1899: Notes on the teeth of sharks and skates from English Eocene formations. Proc. Geol. Ass. 16: $1-14$.

Woodward, A. S. 1921: Observations on some extinct elasmobranch fishes. Proc. Linn. Soc. Lond. 133: 29-39.

Woodward, A. S. 1932: K. A. v. Zittel: Text-book of Palaeontology. Vol. 2. London.
Zangerl, R. 1973: Interrelationships of early chondrichthyans. In: Greenwood, P. H., Miles, R. S. \& Patterson, C. (Eds.): Interrelationships of fishes: 1-14. Linn. Soc. Lond. Academic Press. London.

Zangerl, R. \& Case, G. R. 1973: Iniopterygia, a new order of chondrichtyan fishes from the Pennsylvanian of North America. Fieldiana Geol. Mem. 6: 1-67.

Ørvig, T. 1951: Histologic studies of placoderms and fossil elasmobranchs. 1 . The endoskeleton, with remarks on the hard tissues of lower vertebrates in general. Ark. Zool. (2) 2: 321-454.

Ørvig, T. 1966: Histologic studies of ostracoderms, placoderms and fossil elasmobranchs. 2. On the dermal skeleton of two late Palaeozoic elasmobranchs. Ark. Zool. (2) 19: 1-39.

Ørvig, T. 1967: Phylogeny of tooth tissues: evolution of some calcified tissues in early vertebrates. In: Miles, A. E. W. (Ed.): Structural and chemical organization of teeth, 1: 45-110. Academic Press, New York \& London.

Ørvig, T. 1973: Fossila fisktänder i svepelektronmikroskopet: gamla frågeställninger i ny belysning. Fauna Flora Stkh. 68: 166-173. (In Swedish).

Ørvig, T. 1976a: Palaeohistological notes. 4. The interpretation of osteodentine, with remarks on the dentition in the Devonian dipnoan Griphognathus. Zool. Scr. 5: 79-96.

Ørvig, T. 1976b: Palaeohistological notes. 3. The interpretation of pleromin (pleromic hard tissue) in the dermal skeleton of psammosteid heterostracans. Zool. Scr. 5: 35-47.

Ørvig, T. 1978a: Microstructure and growth of the dermal skeleton in fossil actinopterygian fishes: Birgeria and Scanilepis. Zool. Scr. 7: 33-56.

Ørvig, T. 1978b: Microstructure and growth of the dermal skeleton in fossil actinopterygian fishes: Boreosomus, Plegmolepis and Gyrolepis. Zool. Scr. 7: 125-144.

Ørvig, T. 1978c: Microstructure and growth of the dermal skeleton in fossil actinopterygian fishes: Nephrotus and Colobodus, with remarks on the dentition in other forms. Zool Scr. 7: 297-326.

Ørvig, T. 1980a: Histologic studies of ostracoderms, placoderms and fossil elasmobranchs. 3. Structure and growth of the gnathalia of certain arthrodires. Zool. Scr. 9: 141159.

Ørvig, T. 1980b: Histologic studies of ostracoderms, placoderms and fossil elasmobranchs. 4. Ptyctodontid tooth plates and their bearing on holocephalan ancestry: the condition of Ctenurella and Ptyctodus. Zool. Scr. 9: 219-239. 